OPEN ACCESS

Edited by:

Peter Hegyi,

University of Szeged, Hungary

Reviewed by:

László Czakó,

University of Szeged, Hungary

Søren Schou Olesen,

Aalborg University Hospital, Denmark

*Correspondence:

Stephen J. Pandol

Stephen.Pandol@cshs.org

Ling $\mathrm{Li}$

li-ling76@hotmail.com

${ }^{\dagger}$ These authors have contributed equally to this work

Specialty section:

This article was submitted to

Gastrointestinal Sciences,

a section of the journal

Frontiers in Physiology

Received: 07 June 2020 Accepted: 07 October 2020 Published: 28 October 2020

Citation:

Wei Q, Qi L, Lin H, Liu D, ZhuX,

Dai Y, Waldron RT, Lugea $A$, Goodarzi MO, Pandol SJ and Li L (2020) Pathological Mechanisms in Diabetes of the Exocrine Pancreas:

What's Known and What's to Know.

Front. Physiol. 11:570276.

doi: 10.3389/fphys.2020.570276

\section{Pathological Mechanisms in Diabetes of the Exocrine Pancreas: What's Known and What's to Know}

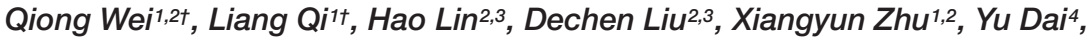 \\ Richard T. Waldron ${ }^{5}$, Aurelia Lugea ${ }^{5}$, Mark O. Goodarzi ${ }^{6}$, Stephen J. Pandol ${ }^{5 *}$ and \\ Ling Li ${ }^{1,2 *}$
}

\begin{abstract}
${ }^{1}$ Department of Endocrinology, ZhongDa Hospital, School of Medicine, Southeast University, Nanjing, China, ${ }^{2}$ Institute of Pancreas, Southeast University, Nanjing, China, ${ }^{3}$ Department of Clinical Science and Research, ZhongDa Hospital, Southeast University, Nanjing, China, ${ }^{4}$ Nanjing Foreign Language School, Nanjing, China, ${ }^{5}$ Division of Gastroenterology, Department of Medicine, Cedars-Sinai Medical Center, Los Angeles, CA, United States, ${ }^{6}$ Division of Endocrinology, Diabetes and Metabolism, Department of Medicine, Cedars-Sinai Medical Center, Los Angeles, CA, United States
\end{abstract}

The clinical significance of diabetes arising in the setting of pancreatic disease (also known as diabetes of the exocrine pancreas, DEP) has drawn more attention in recent years. However, significant improvements still need to be made in the recognition, diagnosis and treatment of the disorder, and in the knowledge of the pathological mechanisms. The clinical course of DEP is different from type 1 diabetes mellitus (T1DM) and type 2 diabetes mellitus (T2DM). DEP develops in patients with previous existing exocrine pancreatic disorders which damage both exocrine and endocrine parts of pancreas, and lead to pancreas exocrine insufficiency (PEI) and malnutrition. Therefore, damage in various exocrine and endocrine cell types participating in glucose metabolism regulation likely contribute to the development of DEP. Due to the limited amount of clinical and experimental studies, the pathological mechanism of DEP is poorly defined. In fact, it still not entirely clear whether DEP represents a distinct pathologic entity or is a form of T2DM arising when $\beta$ cell failure is accelerated by pancreatic disease. In this review, we include findings from related studies in T1DM and T2DM to highlight potential pathological mechanisms involved in initiation and progression of DEP, and to provide directions for future research studies.

Keywords: endocrine, exocrine pancreas, diabetes, chronic pancreatitis, pathological mechanisms

\section{INTRODUCTION: CLINICAL FEATURES OF DEP}

Diabetes of the exocrine pancreas (DEP),refers to diabetes mellitus (DM) secondary to various exocrine pancreatic diseases such as pancreatitis, trauma/pancreatectomy, pancreatic neoplasia, etc. Due to confusion with type 2 diabetes mellitus (T2DM) (Petrov, 2017), it has been underestimated in clinical practice for a long time. The incidence of DEP varies with geographical distribution and etiology (Ewald and Hardt, 2013; Pendharkar et al., 2017; Woodmansey et al., 2017; Bharmal et al., 2020a), with estimated true prevalence ranging from 1 to $9 \%$ of all diabetic patients (Hart et al., 2016). It has been noted that compared to other DM patients, the DEP patients present additional 
symptoms related to pancreatic disease, including decreased glucagon and somatostatin, pancreatic exocrine insufficiency (PEI), malabsorption of nutrients and micronutrients, severe and painful gastrointestinal symptoms, and nutritional deficiencies (Wynne et al., 2019). These additional morbidities promote greater blood glucose fluctuations. Although there have been contradictory observations about glycemic control in DEP (Jethwa et al., 2006; Ewald et al., 2012), it is generally believed that serum glucose levels in DEP are difficult to control, with alternately occurrence of hypoglycemia and hyperglycemia, (also known as "brittle diabetes") (Larsen et al., 1987; Larsen, 1993).

Currently, there is no uniformly recognized diagnostic criterion for DEP. Identification of the disease emphasizes the detection of exocrine pancreatic disorders and pathological changes of the exocrine pancreas different than the autoimmune mechanism which is the characteristic of type 1 diabetes mellitus (T1DM). The current proposed diagnostic criteria include evidence of pancreatic exocrine disease such as functional insufficiency (identified with tests of the fecal elastase-1 or exocrine pancreatic function) and pathological changes of pancreatic imaging [computerized tomography (CT), magnetic resonance imaging (MRI), endoscopic ultrasound], as well as potential alterations in incretin secretion and decreased levels of fat soluble vitamins (A, D, E, and $\mathrm{K}$ ) in serum (Ewald and Bretzel, 2013; Wynne et al., 2019). In addition, certain novel biomarkers showed potential in discriminate DEP from other diabetes (Olesen et al., 2019; Bharmal et al., 2020b; Gold-Smith et al., 2020).

Similar to other DMs, the major goal of DEP treatments is to reduce hemoglobin A1c (HbAlc) levels for minimizing the macrovascular and microvascular complications risk, as well as delay the development of pancreatic cancer. Traditionally, physicians tend to choose similar drugs used to treat T2DM (Rickels et al., 2013), however recent knowledge about the potential differences from other diabetes suggested more careful treatment strategy. Lifestyle adjustment and dietary interventions are critical to improve nutrition status and overall health outcomes. As for the anti-hyperglycemic medication, insulin therapy is preferred for most patients due to common insulin deficiency in DEP patients. In addition, insulin was suggested to benefits nutrition of patients. However, in considering of preserved peripheral insulin sensitivity, the dosing should be titrated, similar as in T1DM. Metformin was suggested to be used in patients with DEP due to chronic pancreatitis (CP), owe to reduced risk of pancreatic ductal adenocarcinoma (PDAC) (Gudipaty and Rickels, 2015; Wynne et al., 2019). Due to potential differences in symptoms and etiology between DMs, personalized hyperglycemia solutions should pay special attention to drug indications and contraindications. For example, although being preferred selections for DM treatment in many situations, incretin-based therapies such as glucagonlike peptide-1 (GLP-1) receptor agonists have been suggested to be associated with increased pancreatitis risk (Buse et al., 2017; Abd El Aziz et al., 2020). Although more thorough studies have suggested that incretin-based treatment did not increase pancreatitis risk (Wang et al., 2015, 2018; Abd El Aziz et al., 2020), it is still suggested to be used with vigilance
(Buse et al., 2017; Abd El Aziz et al., 2020). Therefore, application of these drugs in DEP patients should be done with caution (Alves et al., 2012). Moreover, DM treatments in these patients should be applied in combination with pancreatic enzyme replacement therapy (PERT) for PEI and proper diet to maintain nutritional requirements and the absorption of fat-soluble vitamins (Duggan and Conlon, 2013; Lohr et al., 2017).

\section{ETIOLOGY AND PATHOLOGY OF DEP}

While CP was originally thought to be the most common cause of DEP, the greater numbers of patients with acute pancreatitis (AP) led to recent recognition that $80 \%$ of pancreatitisrelated DEP is due to AP and $20 \%$ to CP (Petrov and Yadav, 2019). The pancreas is composed of both exocrine and endocrine structures. In addition, the endocrine part of the pancreas contains five different types of cells $(\alpha$, $\beta, \delta, P P$, and $\varepsilon)$. The endocrine hormones secreted include glucagon, insulin, somatostatin, pancreatic polypeptide and ghrelin (Da Silva Xavier, 2018; El Sayed and Mukherjee, 2019). Disorders of the exocrine compartment including AP and $\mathrm{CP}$, pancreatic tumor, pancreatic trauma, cystic fibrosis, partial pancreatectomy, hemochromatosis, and pancreatic agenesis precede are characteristics of DEP, with the most common coexisting disorder being pancreatitis (Abu-Bakare et al., 1986; Expert Committee on the Diagnosis and Classification of Diabetes Mellitus, 2003; Ewald et al., 2012; American Diabetes Association, 2019). As a result of exocrine pancreatic disease, DEP is featured with pancreatic tissue damage compromising exocrine cells and cell subtypes within the islets of Langerhans (Walling and Freelove, 2017; Hammad et al., 2018; Pham and Forsmark, 2018). In this respect, DEP is significantly different from T1DM, in which autoimmune damage of $\beta$ cells and secondary inflammation cause relatively limited damage to the exocrine compartment.

While much research indicates that extensive destruction of islet cells is the main reason of the development of DEP from CP (Ewald et al., 2012), $\beta$ cell dysfunction without extensive destruction has also been observed in CP (Sasikala et al., 2012), but the contribution of other endocrine and exocrine cell types to the pathogenesis of DEP is unclear.

Besides cellular damage and dysfunction of pancreatic cells, other factors such as PEI and malnutrition, which are common in DEP, may promote DM pathology through mechanisms involving regulation of incretin secretion and perturbing intestine-pancreas crosstalk. These factors should be addressed in completing our understanding of DEP pathogenesis.

Since research studies specific for DEP are still rare, the understanding of DEP pathology often relies on the current knowledge about the characteristics and mechanisms underlying T1DM and T2DM pathology. It is often the differences in the extensities and combinations of these basic pathological changes that separate different DMs. In the next sections, we review different potential mechanisms involved in the development of DEP. 


\section{CONTRIBUTION OF CHANGES IN $\beta$ CELL MASS AND FUNCTION TO DEP PATHOLOGY}

$\beta$ cells and insulin are the central players in DM development. The $\beta$ mass, referring to the total number of $\beta$ cells, as well as the functional status of these cells, are the major determinant of plasma insulin levels. Reduced cell mass or function can both lead to insufficient insulin levels, which can result in hyperglycemia and diabetes. In T1DM, loss of $\beta$ cell mass, as the result of autoimmune damage of $\beta$ cells, is the main cause of disease. In most cases of T2DM, insulin resistance is the initial pathological mechanism, with hyperglycemia developing when $\beta$ cells fail to compensate with insulin hypersecretion. Dysfunction of $\beta$ cells also plays critical roles in T1DM and T2DM. In T1DM, functional exhaustion and degranulation have been noticed in the remaining $\beta$ cells after long disease period (Rojas et al., 2018). In T2DM, $\beta$ cell compensation is characterized by enhanced insulin secretion and $\beta$ cell hyperplasia, hypertrophy, and increased proliferation. But chronic hyperglycemia will eventually result in $\beta$ cell exhaustion, the reversal of $\beta$ cell structural adaptations evident by hypoplasia, hypotrophy, reduced proliferation, and dedifferentiation, all resulting in insulin hyposecretion (Chen et al., 2017). In addition, dynamics of insulin release may be changed at late stages, presented as damaged response in the first phase, as well as destruction of conventional oscillation release mode (Del Prato et al., 2002). It seemed that changes in cell functions play more important role than cell mass alteration in this process.

Many cases of DEP caused by CP are likely due to the $\beta$ cell mass loss and insulin secretion reduction. It has been reported that $\beta$ cell mass was reduced by approximately $29 \%$ in CP patients; and that reductions in insulin secretion and hyperglycemia occur in CP patients with $\beta$ cell mass $<40 \%$ of the normal (Meier and Giese, 2015). Damages in functional islet mass, and correlated early-phase insulin secretion, was reported in $\mathrm{CP}$ patients with early development of postprandial hyperglycemia (Sheikh et al., 2017). In CP patients, $\beta$ cell function impairment and decrease in exocrine pancreatic function often co-exist. It has been reported that insulin secretion is closely correlated with pancreatic enzyme stimulation. Moreover, in patients with cystic fibrosis, it was noticed that reduced $\beta$-cell secretion capacity was only detected when pancreatic exocrine secretion was insufficient (Nyirjesy et al., 2018).

How important a role that $\beta$ cell mass and functional changes play in the pathogenesis of DEP is still unclear, mainly because of the rarity of human samples. In addition, technologies to investigate human $\beta$ cell mass need to be further perfected. It has been suggested that impairment of $\beta$ cell function may occur at early CP stages, while only when significant fibrosis appears that clinical diabetes symptoms will present (Sasikala et al., 2012). Tissue damage to the pancreas in CP showed significant specificity to the exocrine compartment and has little effect on the endocrine islets, as supported by the non-significant turnover of $\beta$ cells although the number of apoptotic acinar cells increased about 10 times (Schrader et al., 2009). In addition, $\beta$ cell destruction appears to be slower and its function better preserved in CP patients than in comparable T1DM patients. In sum, the evidence suggests that similarly to T1DM and T2DM, dysregulation of insulin secretion function in the $\beta$ cell is an early pathological event in DEP. Loss of total $\beta$ cell mass is also critical in disease progress, but the exact level of $\beta$ cell mass reduction required for disease manifestation has not been determined yet.

\section{CELL DEATH AND INFLAMMATION AS POTENTIAL DRIVERS OF $\beta$ CELL MASS LOSS AND DYSFUNCTION IN DEP}

Various stimulations in diabetes may cause $\beta$ cell death, including inflammatory and immune responses, stress factors such as reactive oxygen species (ROS), endoplasmic reticulum (ER) stress, as well as damages in cell components [such as deoxyribonucleic acid (DNA) fragmentation] and functions such as excessive islet amyloid. The mechanism underlying most cell death process, such as autophagy, inflammasome activation and mitochondrial dysfunction also play important role in $\beta$ cell death (Rojas et al., 2018). In T1DM, $\beta$ cell destruction is induced by an ongoing immune cell infiltration, and is aggravated through ER stress and apoptosis which are caused by disturbed glycemic metabolism (Kurrer et al., 1997). In T2DM patients, the processes underlying $\beta$ cell mass loss are unclear but likely involve increases in $\beta$ cell apoptosis due to insulin resistance and subsequent $\beta$ cell exhaustion.

Inflammation and oxidative stress play critical roles in reduced $\beta$ cell mass in both T1DM and T2DM (Imai et al., 2016; Halim and Halim, 2019; Tsalamandris et al., 2019). Macrophagemediated inflammatory responses within islets were suggested as major contributors of reduced $\beta$ cell survival and function. However, recent studies indicate that macrophages can protect $\beta$ cells during pancreatitis and support $\beta$ cell proliferation and regeneration (Van Gassen et al., 2015). Like in T1DM and T2DM, inflammation plays a central role in DEP. DEP-related disorders including AP, CP, PDAC, and pancreatic surgery all feature local and systemic inflammatory responses (Gukovsky et al., 2013; Sit et al., 2014; Habtezion et al., 2019; Mayerle et al., 2019). Inflammation induced by T-helper in islet has been suggested to contribute to $\beta$ cell apoptosis and dysfunction during CP (Talukdar et al., 2016). Other studies indicate that pancreatic levels of interferon gamma (IFN $\gamma$ ) are significantly higher in diabetic CP patients and induce $\beta$ cell dysfunction via Pancreatic Duodenum Homeobox-1 (PDX-1)-downstream signaling pathways (Pavan Kumar et al., 2012; Pondugala et al., 2015). Inflammation can also increase ROS and $\beta$ cell death by modulating Nrf2/NF- $\mathrm{BB}$ and SAPK/JNK pathways (Choudhury et al., 2015). Cytokine macrophage migration inhibitory factors overexpressed in pancreatic cancer are related to impaired insulin release by $\beta$ cells (Tan et al., 2014). Primary $\beta$ cell destruction in diabetes associated with autoimmune pancreatitis (AIP) may be induced by T-cells (Tanaka et al., 2001).

Although inflammation is a major factor in DM, the source of inflammation varies depending of the disorder. Inflammation in DEP is mainly induced by exocrine pancreatic damage while autoimmune insulitis is the source of inflammation in 
T1DM, and long-term insulin resistance and hyperglycemia are the main drivers of chronic inflammation in T2DM. Whether these factors contribute differentially to $\beta$ cell dysfunction and disease progression in these three DM disorders needs further investigation.

\section{ROLE OF $\beta$ CELL DEDIFFERENTIATION IN DM DISORDERS}

Previous studies have suggested that islet damage and apoptotic $\beta$ cells do not fully explain the decline in $\beta$ cell function in T2DM (Rahier et al., 2008; Cinti et al., 2016). There is increasing evidence that mature $\beta$ cells may, under certain conditions, lose their differentiated phenotype and cell characteristics and degenerate to a less differentiated state. These dedifferentiated cells do not produce insulin, and no longer contribute to glucose homeostasis. So, both dedifferentiation and cell death have been proposed be involved in the damage of $\beta$ cell mass in diabetes (Bensellam et al., 2018). The detailed mechanism of $\beta$-cell dedifferentiation is still unclear. Certain stress related conditions, including inflammation, hypoxia/oxidative stress, and ER stress, may cause $\beta$-cell dedifferentiation. Therefore, it is considered that dedifferentiation may be a mechanism for cells to adapt to the environment changes to avoid death. Beta cell dedifferentiation is reversible before the disease progresses to a certain degree. It has been shown that modulating blood glucose to normal levels can lead to the reversal of $\beta$ cell dedifferentiation.

Talchai et al. (2012) found that $\beta$ cell dedifferentiation is a critical cause of $\beta$ cell function reduction in a mouse model of T2DM. Clinical studies further confirmed that $\beta$ cells can dedifferentiate into $\alpha$ - and $\delta$ - "like" cells in patients with T2DM (Jonas et al., 1999; Cinti et al., 2016; Diedisheim et al., 2018). Further investigations are needed to confirm the role of $\beta$ cell dedifferentiation in damages of $\beta$ cell functions in T2DM.

Using a pancreatic duct ligation (PDL) model of CP to induce $\mathrm{DEP}$, a recent study showed that the decrease in the number and function of $\beta$ cells caused by was due to dedifferentiation rather than apoptosis of $\beta$ cells, and was associated with inflammatory cell infiltration (Xiao et al., 2017). In the islets of $\mathrm{CP}$ patients, more than $10 \%$ of $\beta$ cells undergo dedifferentiation, and the dedifferentiation rate of $\beta$ cells continues to accelerate during the progress of the disease (Sun et al., 2019). These phenomena suggest that the dedifferentiation of $\beta$ cells may be an important cause of DEP.

\section{$\beta$ CELL REPLICATION, TRANSDIFFERENTIATION, AND NEOGENESIS IN DM DISORDERS}

In T1DM and T2DM, compensatory mechanisms operate to preserve $\beta$ cell mass. Studies in various rodent pancreatic islet injury models and samples from children after pancreatectomy have demonstrated the regeneration of $\beta$ cells (Collombat et al., 2010; Sharma et al., 2017; Shi et al., 2018). Furthermore, increasing $\beta$ cell mass has been noticed during various clinical conditions, including pregnancy and obesity that can cause islet hyperplasia, as well as in animal models of insulin resistance (Ouyang et al., 2011). Studies of genetic lineage tracing in mice show that replication of pre-existing $\beta$ cells is the main resource of $\beta$ cell replenishment, in both healthy and injured conditions. However, it is less clear about how big a role of replication plays in humans (Cerf, 2013).

In addition, one report shows both aand $\delta$ cells may transdifferentiate into $\beta$ cells when more than $99 \%$ of $\beta$ cells in mice are ablated resulting in recovery of $\beta$ cell mass over several months, depending on the age of the mice (Zhou and Melton, 2018). The molecular mechanism and whether such conversions also occur in humans remain to be explored.

The existence of pancreatic stem cells (or known as progenitor cells) has been suggested. It has been reported that new islet cells could be generated directly from ducts (referred to as neogenesis) (Bonner-Weir et al., 2012). In another study, it was shown that a population of cells with positive expression of neurogenin 3 (Ngn3), indicating the function of these cells as endocrine precursor, appeared around islets and ducts after PDL in experimental animal models (Magenheim et al., 2011). In $\mathrm{T} 2 \mathrm{DM}$, neogenesis but not proliferation was suggested to be a potential mechanism for the increase of $\beta$-cell mass in subjects with insulin resistance and impaired glucose tolerance. The existence of adult pancreatic stem cells still needs to be further clarified (Zhou and Melton, 2018).

Several studies have suggested $\beta$ cell compensation may occur in DEP. For example, in mice model of cerulein-induced pancreatitis, it is possible to generate $\beta$ cells from cytokeratin 5positive cells (Shi et al., 2018). Leukemia inhibitory factor induced activation of the Jak/Stat signaling induced non-endocrine pancreatic cells trans-differentiating into insulin-producing cells (Yamauchi et al., 2015). Lineage-tracing studies present evidence that exocrine cells undergo dedifferentiation into a progenitorlike state from which they can be manipulated to form insulinproducing cells (Jawahar et al., 2019). Cells with a positive expression of chromogranin $\mathrm{A}$, but no hormone production [known as chromogranin A positive hormone-negative (CPHN) cells], are highly abundant in neonatal, therefore are considered as candidate of newly formed endocrine cells. The regeneration of endocrine cell has been suggested by the appearance a lobular distribution of these CPHN cells in CP (Moin et al., 2018). It was suggested that a microenvironment suitable for regeneration of acinar- and $\beta$ cell could be induced by activated macrophages (Criscimanna et al., 2014). Therefore, similar $\beta$ cell compensatory mechanisms as in T1DM and T2DM may play important role in DEP. However, whether there is a difference in proportions of various compensations and the source of compensatory $\beta$ cells in different types of DM needs to be determined.

The potential mechanisms involved in controlling $\beta$ cell mass and function are summarized in Figure 1.

\section{$\alpha$ CELL AND GLUCAGON RESPONSE}

The $\alpha$ cells of Langerhans islets secrete glucagon, which acts on the hepatocytes to enhance glycogenolysis and gluconeogenesis. 


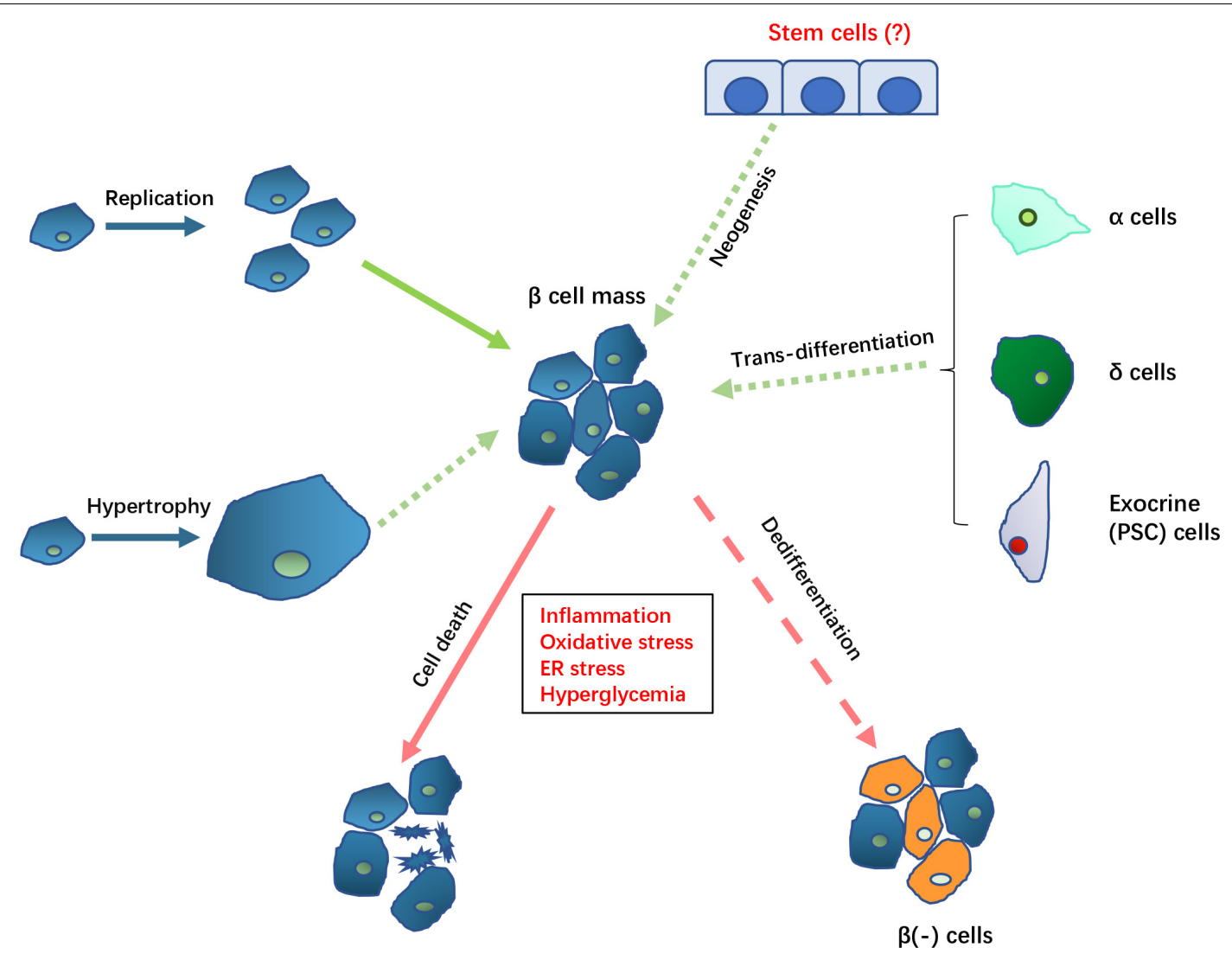

FIGURE 1 | Potential mechanisms controlling $\beta$ cell mass in DEP. The loss of $\beta$ cell mass (indicated by arrows with red lines) in DEP could result from cell death and $\beta$ cell dedifferentiation which causes loss of $\beta$ cell function and specific markers. The loss of $\beta$ cell mass may be compensated (indicated by arrows with green lines) by replication or hypertrophy by remaining $\beta$ cell, trans-differentiation from non- $\beta$ cells, as well as neogenesis of new $\beta$ cell from potential existing stem cells. Solid arrows indicate known mechanisms while dotted arrows indicate the potential mechanisms that need to be further clarified in DEP.

In T1DM, reduced cell mass in endocrine islets appears to be highly specific to $\beta$ cells. It has been reported that three quarters of islet were composed of $\alpha$ cells, and the level of circulating glucagon can be markedly elevated despite hyperglycemia (Gromada et al., 2018). Studies in T1DM have shown that in addition to causing hyperglycemia through increased level of glucagon, a cell dysfunction may also result in insufficient glucagon release in situation of hypoglycemia. Hyperglucagonemia in T1DM is thought to be due to hypertrophy and hyperplasia of $\alpha$ cell. In addition, loss of insulin influence may cause disinhibition of $\alpha$ cells and play a role in hyperglucagonemia (Campbell and Drucker, 2015). T2DM patients are often detected with enduring fasting hyperglucagonemia, as well as insufficient postprandial suppression of glucagon levels, suggesting glucagon as an important contributor to the hyperglycemia of T2DM. Although whether $\alpha$ cell mass is unchanged or increased in patients with T2DM is debatable, the $\alpha$ to $\beta$ cells ratio is significantly higher in T2DM patients due to the decreased $\beta$ cell mass (Campbell and Drucker, 2015). It was suggested that in patients with T2DM, $\alpha$ cell mass and glucagon secretion were enhanced by high glucose, lipids, and inflammatory cytokines. Hyperglucagonemia is considered to be caused by $\alpha$ cell resistance to the inhibitions of insulin and hyperglycemia. In addition, dysregulation of incretins, may also be involved since the incretins function as suppressor of glucagon release. $\alpha$ cells have higher resistance to toxicity stimulation of glucose, lipid, and cytokines, which might be potential cause for relatively less affected $\alpha$ cell mass. Impaired glucagon secretion could lead to decreased hepatic glucose production in spite of dangerously low blood glucose levels (hypoglycemia unawareness) (Andersen et al., 2018; Gromada et al., 2018). In addition, impaired $\alpha$ cells severely limits the ability to regulate treatment related hypoglycemia (Lin et al., 2015), which used to be considered a minor problem in T2DM, but is now thought to be underestimated and drawing more attentions due to elevated usage of insulin treatment (Zammitt and Frier, 2005).

Glucose counter regulation was reported to be retained with slightly damage in CP related DM patients, even with no residual $\beta$ cell function (Larsen et al., 1990). Even when glucagon secretion could not be properly stimulated by insulininduced hypoglycemia in CP related DM patients, preserved catecholamine response to hypoglycemia largely preserved glucose counterregulation. These findings suggest that in insulindependent diabetes mellitus secondary to $\mathrm{CP}$, the adverse response to hypoglycemia may be avoidable. High somatostatin 
levels may help lower blood sugar levels in CP patients (Larsen et al., 1988). In a study of DM after CP along with T2DM, in both diseases, the response of $\alpha$ cell $s$ to oral glucose intake and hypoglycemia was similarly disrupted, suggesting a common etiology arising secondary to DM development (Mumme et al., 2017). Islet $\alpha$ cell inflammation was suggested to be among the cause of hypoglycemia (Li et al., 2018). In CP patients with low BMI, elevated levels of $\alpha$ cells have been reported to emanate from the pancreatic duct (Webb et al., 2018). As a special type of CP, AIP patients who underwent steroid therapy showed improved pancreatic $\alpha$ cell function but only partial improvement of $\beta$ cell function (Takeshima et al., 2018). This imbalance between $\alpha$ cell and $\beta$ cell function may contribute to difficulties in glucose control in DEP.

\section{PANCREATIC POLYPEPTIDE (PP) CELLS}

PP cells are mainly distributed in the pancreas head, with pancreatic polypeptide as their endocrine hormone product (Rahier et al., 1983). Since the $\beta$ cells are surrounded by PP cells, a protective role was suggested for PP cells. PP can stimulate insulin secretion in isolated islets. The mechanism was suggested to be mainly through the inhibition of somatostatin secretion (Kim et al., 2014). In T2DM, PP levels is elevated, which causing decreased secretion of somatostatin, which may be a compensatory mechanism to regulate glycemia. Experiments in animals showed that infusion of PP could not improve glucose tolerance, neither did it increase the release of insulin. However, PP decreased hepatic glucose production, which may improve hepatic insulin sensitivity (Hennig et al., 2002). These results suggest that $\mathrm{PP}$ can reduce the liver's glucose production by reducing hepatic insulin resistance. Hepatic insulin resistance has been reported in $\mathrm{CP}$, which may be caused by decrease in PP. In addition, damage to the PP receptor stimulation signal of the hepatic cells may also be involved (Sliwinska-Mosson et al., 2017).

Decreased PP production has been suggested to be an earl marker of islet dysfunction. Patients with $\mathrm{CP}$ remain at low PP levels which are associated with the severity of the degree of pancreatic lesions. Impairment of postprandial PP response is among the earliest manifestations of pancreatic endocrine abnormalities in CP (Hanafusa et al., 1982). Functional impairment of PP cells and significant loss of PP response can be observed in DEP patients with complete destruction of $\beta$ cells (Larsen et al., 1988). PP secretion was absent in CP without endogenous insulin production. In AP and CP, PP has been suggested to be used as a diagnostic marker as well as treatment target of DEP (Hennig et al., 2002). However, fasting PP levels are similar in $\mathrm{CP}, \mathrm{PDAC}$, and controls regardless of glycemic status (Nagpal et al., 2018), indicating that PP might not be a specific diagnostic marker for DEP. In addition, 58\% of patients with CP were reported to be with normal levels of $\mathrm{PP}$, suggesting that $\mathrm{PP}$ may be not a sensitive marker for diagnosis of CP (Andersen et al., 1980). PP response to mixed meal may be a better biomarker to help distinguish DEP from other types, a hypothesis that we are currently testing (Hart et al., 2018). Hepatic insulin resistance was reported in DEP patients with preceding $\mathrm{CP}$, PDAC, pancreatectomy and cystic fibrosis (Seymour et al., 1988; Cersosimo et al., 1991; Kien et al., 1995; Brunicardi et al., 1996). CP accompanied by PP deficiency is associated with partial hepatic resistance in both regular condition and situations of hyperinsulinemia (Brunicardi et al., 1996). A previous study showed that PP supplementation can improve hepatic insulin sensitivity and reduce glucose production by the liver (Brunicardi et al., 1996). However, absent PP secretion may not have a major effect on glucoregulation in diabetes secondary to $\mathrm{CP}$ (Larsen, 1993).

\section{$\delta$ CELL AND SOMATOSTATIN}

The $\delta$ cells secrete somatostatin when glucose is elevated. Once released, somatostatin functions on islet cells through its receptor (SSTRs) as a local paracrine agent. Somatostatin has a large number of effects on $\alpha$ and $\beta$ cells, which together leads to a decrease in secretion of insulin and glucagon. Somatostatin also have influences on $\beta$ cell. It can modulate the apoptosis and proliferation of mouse $\beta$ cells in response to stress (Damsteegt et al., 2019). In addition, $\delta$ cell can direct transdifferentiate $\beta$ cell therefore plays a role in $\beta$ cell mass. It has been reported that in diabetes, restoration of $\beta$ cells could result from reprogramming of pancreatic $\delta$ cells into insulin producers (Chera et al., 2014). The latter results are consistent with the hypothesis of cell plasticity. Transdifferentiation between $\alpha, \beta$, and $\delta$ cells may be an important mechanism for the regulation of islet function and participate in physiological and pathological processes. How big a role this cell plasticity, and somatostatin regulation plays in human remains to be further studied (Rorsman and Huising, 2018).

Although the importance of somatostatin in both diabetes and pancreatic disease have been realized, its role in DEP settings has not been thoroughly studied. It has been previously reported that plasma somatostatin levels increased in patients with insulin-dependent DM after CP. The source of these somatostatins is still need to be clarified. However, it is known that somatostatin may help lower blood glucose in patients with insufficient endogenous insulin secretion by inhibiting glucagon secretion (Larsen, 1993). One of the functions of somatostatin is to regulate GLP-1 release. It has been reported that the GLP-1 response seems intact in DEP, while the response to glucose-dependent insulinotropic polypeptide (GIP) is reduced, similarly, as in T2DM (Hedetoft et al., 2000; Knop et al., 2007a). Postprandial secretion of GLP-1 is significantly elevated after trypsin replacement therapy in CP patients (Knop et al., 2007c).

\section{$\varepsilon$ CELL AND GHRELIN}

$\varepsilon$ cell was the fifth endocrine cells identified in pancreatic islet cells, which producing the ghrelin hormone (Wierup et al., 2002). Ghrelin functions through regulating the functions of other endocrine cells (Sakata et al., 2019). Ghrelin inhibits the secretion 
of insulin from $\beta$ cells via paracrine interaction between $\delta$ cells and $\beta$ cells. Transcriptome analysis showed that ghrelin had specificity in activating $\delta$ cells to enhance somatostatin release (DiGruccio et al., 2016). It also stimulates appetite and growth hormone secretion. In addition, ghrelin also plays a role in regulating pancreatic development and physiology, participates in regulating the proliferation and vitality of $\beta$ cells. In addition, it can also play a role in inhibiting endocrine and pancreatic acinar function. Ghrelin is currently an important research target in T2DM and obesity, and its multiple roles in energy metabolism have received widespread attention (Yada et al., 2014; Churm et al., 2017; Napolitano et al., 2018). The role of $\varepsilon$ cells and ghrelin in DEP has not been well documented. Giving the multiple functions it exerts in pancreatic function and nutritional status, its involvement in the pathogenesis of DEP need to be further explored.

Damage and dysfunction of the endocrine islet cells are important mechanisms for DEP pathogenesis. Both insulin and glucagon levels are decreased due to the destruction of $\beta$ and $\alpha$ cells, accompanied with decreased PP and increased somatostatin levels. The microenvironment stimulation and signaling in the pancreatic islet may affect proliferation of $\beta$ cell (Aamodt and Powers, 2017). A perspective from multiple intra-islet cell interconversion may facilitate a more thorough understanding of the endocrine pathological mechanism of DEP.

The overall changes of endocrine pancreatic islet cells and hormones are summarized in Figure 2.

\section{EXOCRINE PANCREAS: PANCREATIC STELLATE CELLS (PSCS)}

Acinar cells and duct cells are the major components of exocrine pancreas. The pathogenetic changes of these cells may have influences on the structure and functions of endocrine islet as well. Activated PSCs play a central role in regulating extracellular matrix (ECM) protein synthesis and degradation (Omary et al., 2007; Apte et al., 2011) and was suggested to be correlated with occurrence and progression of $\mathrm{CP}$ and pancreatic cancer (Apte et al., 2015). PSCs also secrete various cytokines (Xue et al., 2018), which cause $\beta$ cell dysfunction (Zang et al., 2015), leading to hyperglycemia, further aggravating the adverse effects of PSCs on $\beta$ cells (Zechner et al., 2014; Zha et al., 2014). PSCs-induced $\beta$ cell dysfunction can be summarized as three components: (1) physical destruction of islets caused by a large number of ECM, such as collagen I and fibronectin, resulting in pancreatic fibrosis, which leads to islet dysfunction (Sasikala et al., 2012; Hart et al., 2016); (2) pathogenic factors such as inflammatory cytokines, oxidative stress and subsequent inflammatory response lead to islet dysfunction; (3) potential role of exosomes secreted by PSCs. In addition, although the relevant experimental evidence is still insufficient, studies have found that PSCs have characteristics of stem/progenitor cells, suggesting that PSCs may have potential in pancreatic and islets regeneration and thus could play an important role in treatment of DEP in the future (Apte et al., 1998; Trim et al., 2000; Lardon et al., 2002; Joanette et al., 2004).

\section{INSULIN RESISTANCE}

In the past, insulin resistance was considered to be an unimportant contributor to DEP related to CP (Kumar et al., 2017). However, changes in insulin sensitivity have been documented in CP (Vlasakova et al., 2002), and DEP caused by total pancreatectomy (Yki-Jarvinen et al., 1986). One study of 30 patients with CP (4 normal glucose tolerant, 4 impaired glucose tolerant, 22 diabetic) found insulin resistance was present in 22 of the 30 patients and was more common in those with impaired glucose tolerance (IGT) (3 of 4) and diabetes (17 of 22) (Niebisz-Cieslak and Karnafel, 2010). A physiologic study of preoperative patients with pancreatic cancer also found higher insulin resistance compared to matched controls (Cersosimo et al., 1991). Traditional T2DM risk factors for insulin resistance such as family history, obesity was also important in DM development in CP patients (Bellin et al., 2017). In fibrocalcific pancreatic diabetes (FCPD), although insulin secretion defects are considered major cause, the potential involvement of insulin resistance in pathogenesis has been more oftenly recognized (Dasgupta et al., 2015; Aiswarya et al., 2019). In AP, DEP was more frequently present in patients with higher disease severity of AP (Vujasinovic et al., 2014), and insulin resistance index was higher among these patients (Wu et al., 2011). In pancreatic cancer-associated diabetes, Galectin-3 and S100A9, which are related to DM development were reported to mediate insulin resistance (Liao et al., 2019).

\section{POTENTIAL DEP PATHOLOGICAL MECHANISMS BASED ON PANCREATIC EXOCRINE INSUFFICIENCY (PEI)}

Pancreatic diseases are often accompanied with PEI and malnutrition. In AP, prevalence of PEI during admission was 62 and 21-35\% during follow up (Vujasinovic et al., 2014; Tu et al., 2017; Huang et al., 2019). After pancreatectomy, PEI was reported to develop in $36-76 \%$ of the patients with mean time to onset of 14-40 months (Lee et al., 2013; Beger et al., 2018; Hallac et al., 2019; Kusakabe et al., 2019). PEI facilitates pathology of DEP through malnutrition, regulation of incretin secretion, and crosstalk with intestinal flora.

\section{INFLUENCE OF PEI AND MALNUTRITION}

It is well known that CP patients are often with deficient nourishment due to malabsorption and increased metabolic activity (Shimosegawa, 2019). For example, CP patients often have decreased lean body mass and fat mass, which could lead to decreased functional capacity and further weight loss (Gilliland et al., 2017). The causes of CP nutritional deficiencies are multifaceted, including exocrine and/or endocrine dysfunction, severe abdominal pain, etc. leading to less food intake, often persistent alcohol consumption, and increased metabolic activity (O'Brien and Omer, 2019). The malnutrition 


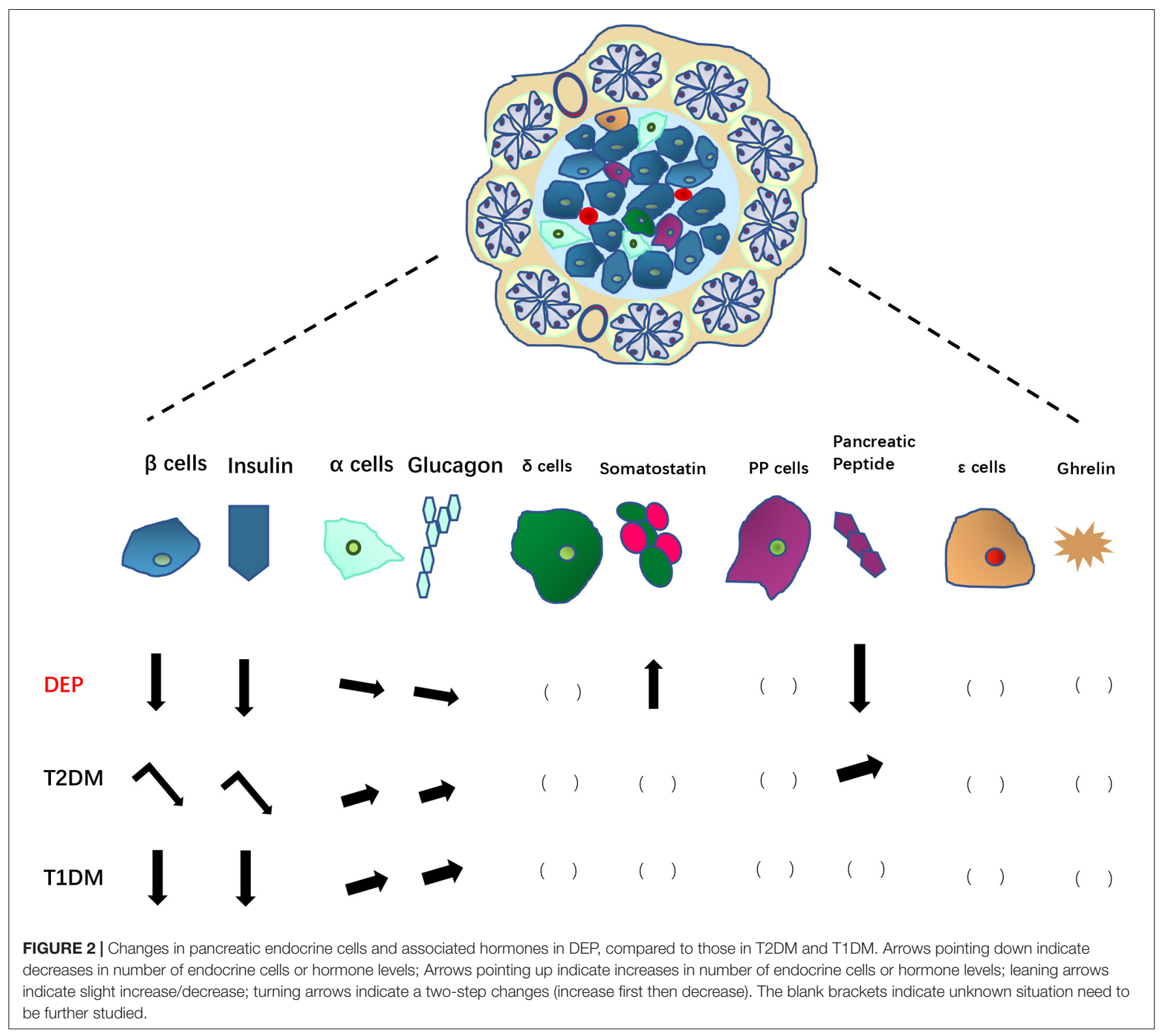

severity was reported to be correlated with malabsorption and nutrients depletion, as well as increased metabolic activity (Rasmussen et al., 2013).

Pancreatic disease has differential effects on various nutrient components. In PEI, carbohydrate digestion is maintained, protein digestion is mildly impaired, while lipid digestion is most significantly impaired. Digestion of protein mainly depend on proteolytic activity in the stomach rarely damaged in CP. Lipids are mainly digested in the small intestine, and pancreatic lipase and coenzyme play a key role in this process. Due to the dysfunction of lipid digestion in CP patients, deficiency of fat-soluble vitamins $\mathrm{A}, \mathrm{D}, \mathrm{E}$, and $\mathrm{K}$ are common. In addition, insufficient secretion of pancreatic protease may cause vitamin B12 deficiency. Mineral intake and absorption are also affected in pancreatic disease (Papazachariou et al., 2000; Vujasinovic et al., 2019). Several markers change significantly in patients with PEI, including albumin, phosphorus, and fatsoluble vitamins (Alexandre-Heymann et al., 2019). Reductions of plasma amino acid levels have also been seen in CP, particularly sulfur containing amino acids and branched chain amino acids (Girish et al., 2011).

Changes of nutrient substrates may play a role in DM development. For example, various free fatty acids (FFA) have may cause various effects on different physiological processes, such as changing the formation and decomposition of adipose tissue, resulting in corresponding changes in endocrine and inflammatory responses. It may also cause changes in cell membrane composition. These effects of plasma FFA may eventually lead to insulin resistance (Sobczak et al., 2019). High levels of saturated FFA have been suggested to be correlated with impaired glucose tolerance in both T1DM and T2DM (Maulucci et al., 2016). Diacylglycerol signaling pathway 
regulates pancreatic $\beta$ cells and insulin secretion (Kaneko and Ishikawa, 2015). Ceramide also plays a critical role in DM development (Galadari et al., 2013). The relation between nutritional substrates and diabetes has mostly been studied at level of vitamin deficiency. The correlation with disease risk and role in glycemic control of vitamin D in T2DM has been widely studied by many researchers including us (Wu et al., 2017; Munoz-Garach et al., 2019). In addition, mineral and amino acid levels appear to influence the risk of diabetes development. As a secondary disease of pancreas injury, in the study of DEP, attention needs to be paid to the role of malnutrition and deficiency of various substrates.

\section{INCRETIN: GUT-ISLET HORMONE INTERACTION}

Gut-islet interactions, mainly through incretin hormones has been widely studied. GLP-1 is mainly produced by L cells in the ileum and large intestine, while $\mathrm{K}$ cells are the main sources of GIP (Holst et al., 2009). During food intake, incretin hormones are released by these intestinal endocrine cells to facilitate insulin secretion response to glucose. Most of postprandial insulin secretion are induced by incretins. Then the rapid degradation of incretins by dipeptidyl peptidase IV (DPP-IV) ensures a transient response. Studies have shown a consistent correlation of the concentration of these peptide hormones with glycemia. In T2DM, GLP-1 secretion appears to be deficient while there appears to resistance to GIP (Nauck et al., 1993). Incretinbased pharmacotherapies (GLP-1 receptor agonists and DPP-IV inhibitors) have become popular choices in clinical treatment of diabetes. However, rather than the main cause leading to T2DM, the deficiency of incretin was more often considered as a results of deteriorating glucose homeostasis in T2DM (Knop et al., 2007b; Knop, 2010). Incretin-based pharmacotherapy has been suggested to be correlated with increased risk of AP in T2DM patients (Azoulay et al., 2016; Ueberberg et al., 2016; Tseng et al., 2017) although more recent and thorough studies have suggested that incretin-based treatment does not increase pancreatitis risk (Wang et al., 2015, 2018; Abd El Aziz et al., 2020). The GLP-1 receptor may activate PSCs, changes pancreatic gene, and enhances pancreatic mass, therefore inducing pancreatic injury (Koehler et al., 2009; Yang et al., 2013).

In normal conditions, the release of incretin hormones is mainly induced by fatty acids and other nutrients. Thus, deficiency in pancreatic exocrine function, which causes impaired fat digestion, may result in impaired incretin response, causing adverse effects on insulin release and blood glucose control. In addition, as discussed above, in settings of pancreatic disease and DEP, damage to $\delta$ cells and somatostatin may affect development of DM though influence on incretin hormone response. Some studies suggested that in DEP, patients are still sensitive to GLP-1, while GIP induced insulin secretion response is damaged, similar as in T2DM (Hedetoft et al., 2000; Knop et al., 2007a). However, in CP patients with normal glucose tolerance, the effect of intestinal incretin was preserved, while in patients with secondary $\mathrm{DM}$, the effect of incretin was strongly reduced, indicating that incretin deficiency is the result of diabetes rather than pancreatitis (Knop et al., 2007b). In contrast, a different study in CP with or without diabetes found reduced GIP responses to a test meal in both groups, with no correlation with exocrine insufficiency (Gomez-Cerezo et al., 1996). Differing results between studies may reflect the meal tested; a study in CP found similar GIP response as controls to a mixed meal but a reduced response to a $100 \%$ fat meal (Ebert and Creutzfeldt, 1980).

Incretin functions in regulating survival, cell growth and differentiation of pancreatic cells which may play a role in $\beta$ cell restoration and genesis (Tasyurek et al., 2014). For example, pueraria tuberosa tubers (PTY-2), which acts as an incretin receptor agonist, has been shown to inhibit $\beta$ cell apoptosis therefore protects streptozocin (STZ)-induced diabetes (Srivastava et al., 2018). GLP-1 and gastrin signaling induce in vivo reprogramming of pancreatic exocrine cells into $\beta$ cells (Sasaki et al., 2015). Considering the complicated effects of incretins on exocrine function deterioration and potential $\beta$ cell protection, their roles in DEP pathogenesis, as well as the choice of incretin-based therapy in these patients need more careful studies.

\section{ORGAN CROSSTALK: INTESTINAL MICROBIOTA}

The gastrointestinal microbiota is an important physiological factor that has emerged in recent years. The composition of the gut microbiota is affected by a number of factors, including diet, disease state, drugs, and host inheritance (TorresFuentes et al., 2017). Changes in the composition of intestinal microbiota, which exert regulatory functions on metabolism and inflammation through various organs (Armutcu, 2019; Tilg et al., 2019). Microbial imbalances (also known as dysbacteriosis) are associated with immune effector cells dysregulation, as well as the levels of inflammatory cytokines, therefore are considered an important factor in different inflammation- mediated diseases (Memba et al., 2017).

A disturbed intraduodenal milieu and pancreatic damage in advanced CP may lead to changes in the intestinal microbiota. Impaired intestinal mucosal barrier integrity plays a critical role in microbiota changes. The changes in intestinal ecological system and bacterial metabolism may in turn affect diabetes and metabolic abnormalities (Jandhyala et al., 2017). Therefore, it is a possibility that gut microbiota might play an important role in DEP. There has been already a small number of reports on intestinal microbiota in DEP, especially which secondary to CP. The most recent study in India enrolled healthy control, CP patient, and DEP patients secondary to CP. Significant differences in the abundance of certain bacteria species, including phylum Bacteroidetes and Faecalibacterium were identified among the three groups (Jandhyala et al., 2017). A reduction in the abundance of Faecalibacteriumprausnitzii and increase in plasma endotoxin were observed in non-diabetic CP, which was more pronounce in $\mathrm{CP}$ with diabetes. There was a significant negative correlation between fasting and postprandial blood glucose with the abundance of Faecalibacteriumprausnitzii, 
and a positive correlation with plasma insulin levels with bacteria, suggesting that intestinal microbial disorders are associated with metabolic changes in $\mathrm{CP}$.

The potential pathological mechanisms of DEP through the influence of PEI are summarized in Figure 3.

\section{SUMMARY}

Due to the lack of consensus diagnostic criteria and experimental animal models, our knowledge of the pathophysiologic mechanisms underlying DEP is still at a very early stage. DEP is characterized by prior pancreatic disease especially AP and CP. Therefore, damage in the whole pancreas, including all endocrine cells and exocrine pancreas, as well as interactions among these cells, need to be considered when exploring DM development.

Physiologically, DEP patients exhibit significant reduced $\beta$ cell functions, including both $\beta$ cell mass and insulin secretion capability. In addition to the direct cell death due to the stress environment in pancreatic disease, other mechanisms involved in $\beta$ cell mass and function control, such as dedifferentiation, transdifferentiation and neogenesis need to be further explored. The interchangeable features of different endocrine cells highlight the need to carefully quantify different types of cells in DEP.

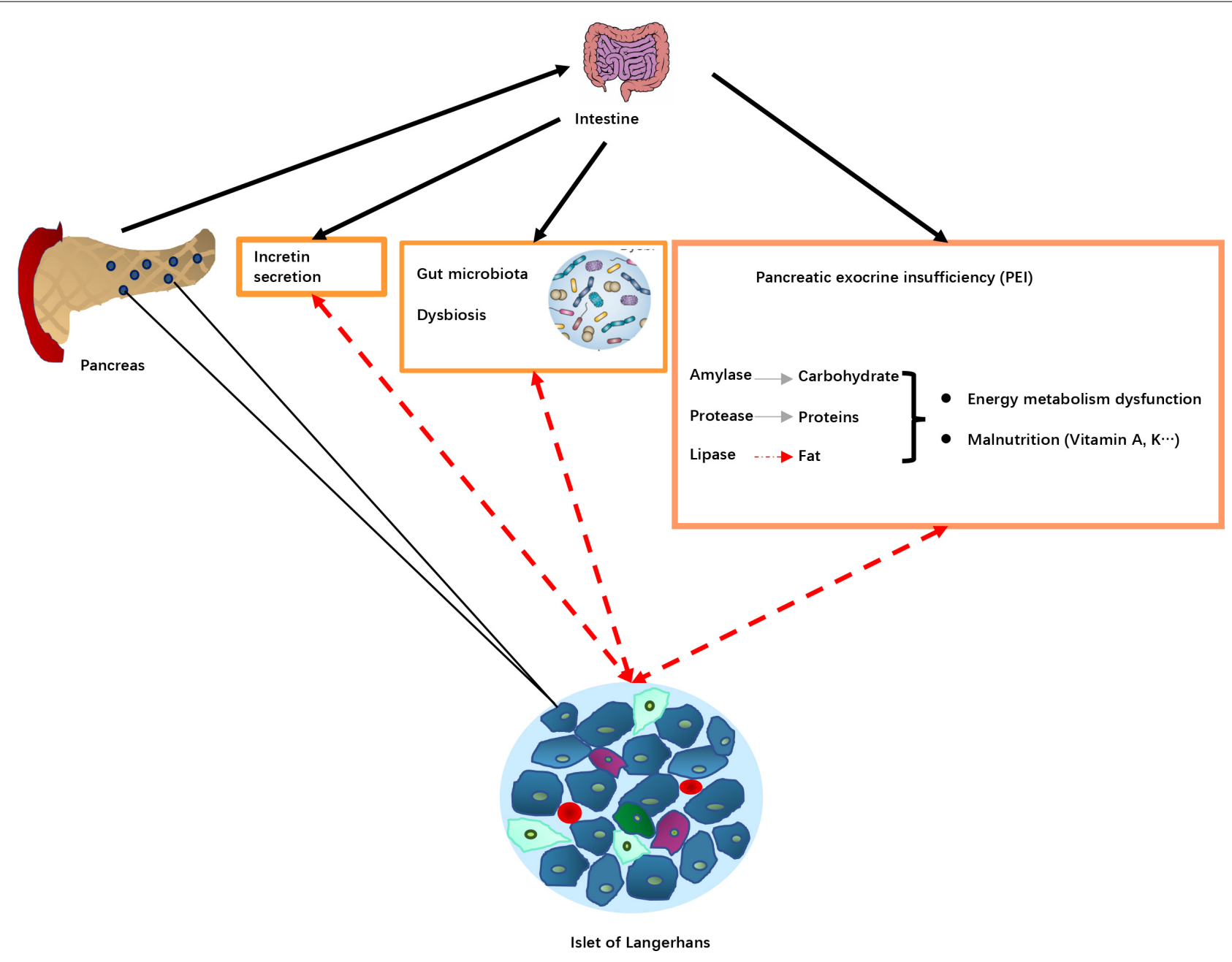

FIGURE 3 | Potential pathological mechanisms associated with pancreatic exocrine insufficiency (PEI) in DEP. Pancreas damage in DEP leading diseases results in reduced release of digestive enzymes into the intestine, that in turn leads to PEI, decreased food digestion and malnutrition. PEI may also affect incretin secretion and the gut microbiota resulting in dysbiosis. These changes alter islet of Langerhans function (dotted red arrows), resulting in changes in production and release of hormones involved in blood glucose regulation. Pancreas damage in DEP leading diseases results in reduced release of digestive enzymes into intestine and impaired nutrient digestion, causing PEl. Lipid digestion is the most significantly affected, which in turn can cause deficiency of fat-soluble vitamins, as well as intake of some minerals. The malnutrition status may play a role in DM development. For example, disturbed plasma lipid profiles may lead to insulin resistance, and certain vitamin deficiency could increase risk of insufficient glycemic control. In addition, PEl and impaired fat digestion can result in impaired release of incretin hormones, glucagon-like peptide-1 (GLP-1) and glucose-dependent insulinotropic polypeptide (GIP), which are the main regulator of insulin release and blood glucose control after meal, as well as regulator of $\beta$ cell mass through regulation of survival and differentiation of multiple types of pancreatic endocrine cells. Furthermore, a disturbed intraduodenal milieu and pancreatic damage in advanced CP may lead to changes in the intestinal microbiota. The changes in intestinal ecological system and bacterial metabolism may in turn affect diabetes and metabolic abnormalities. 
Alpha cells appear to be less impaired in DEP, however, the glucagon response could be compromised due to increased somatostatin. The imbalance between $\beta$ and $\alpha$ cells may also contribute to glycemic control difficulties in DEP.

PP plasma levels were reduced in CP, especially in CP with DM. However, it seems to be a result of higher sensitivity of $\delta$ cells to inflammation damage and PP deficiency does not appear to play a critical role in DM development.

PEI is common in DEP. PEI may affect DM development through malnutrition, dysregulation of incretins that play a critical role in glucose homeostasis, and cross-talk with the intestinal microbiota.

Considering all of the above information, we suggest that studies on pathological mechanisms of DEP should concentrate on the following directions:

(i) In clinical settings, the priority is to establish the diagnosis standard and screening procedure of DEP. A clearly defined and easily applicable diagnostic criterion should precede all effective clinical studies of DEP pathological mechanism.

(ii) $\beta$ cell mass and function regulation, especially mechanisms related to inflammation regulation should be the most important pathological mechanism considered. We suggest the priority in DEP studies should be to clarify the threshold of $\beta$ cell mass that causes hyperglycemia, as well as inflammatory cytokines and immune cell infiltration in the endocrine islet.

(iii) The involvement of other pancreatic cells (mainly endocrine islet cells) in DM pathology should be given more attention. Clarification of the detailed compositions of cell types in islets during DEP disease development will provide substantial information on the pathological progress.

(iv) PEI related mechanisms in DEP should be further elucidated. The level and changes of intestinal hormones, compositions of intestinal microbiota as well as their metabolites will provide further knowledge of systemic causes of DEP.

(v) In basic research of DEP pathological mechanisms, experimental systems, both animal models and coculture cell system are warranted. On the cellular level, dedifferentiation, transdifferentiation and neogenesis of

\section{REFERENCES}

Aamodt, K. I., and Powers, A. C. (2017). Signals in the pancreatic islet microenvironment influence beta-cell proliferation. Diabetes Obes. Metab. 19(Suppl. 1), 124-136. doi: 10.1111/dom.13031

Abd El Aziz, M., Cahyadi, O., Meier, J. J., Schmidt, W. E., and Nauck, M. A. (2020). Incretin-based glucose-lowering medications and the risk of acute pancreatitis and malignancies: a meta-analysis based on cardiovascular outcomes trials. Diabetes Obes. Metab. 22, 699-704. doi: 10.1111/dom.13924

Abu-Bakare, A., Taylor, R., Gill, G. V., and Alberti, K. G. (1986). Tropical or malnutrition-related diabetes: a real syndrome? Lancet 1, 1135-1138. doi: 10. 1016/s0140-6736(86)91846-5 $\beta$ cells, especially from other endocrine and exocrine pancreatic cells are of great importance.

It should be kept in mind that DEP, although different from T1DM and T2DM in clinical features, may possess similar basic pathological mechanisms when considered at tissue and cellular levels. In T1DM and T2DM, the risk of pancreatitis is elevated. As systemic diseases originate from damage/dysfunction in pancreatic islets, the differences between different types of DMs may be subtle. DEP with different preceding pancreatic diseases may show different similarities to T1DM and T2DM. For example, a recent study comparing genetic risks between diabetes associated with $\mathrm{CP}$ (CP-DM) and T2DM found that the two diseases have similar characteristics in single nucleotide polymorphisms, suggesting that CP-DM may be a subtype of T2DM (Goodarzi et al., 2019). Further exploration of pathological mechanisms, besides application in optimization of clinical management, may results in new classifications of the types of DM in the future. It should be pointed out that DEP is comprised of several distinct diabetes subtypes such as PPDMA (post-acute pancreatitis diabetes mellitus), PPDM-C (post chronic pancreatitis diabetes mellitus), PCRD (pancreatic cancerrelated diabetes), and CFRD (cystic fibrosis-related diabetes) (Petrov, 2017). The literature reviewed in this article were mainly in PPDM, especially PPDM-C. Since different subtypes of DEP seem to have different underlying pathophysiological mechanisms, specific attention should be paid in studies of other subtypes of DEP.

\section{AUTHOR CONTRIBUTIONS}

QW and LQ wrote the first draft. HL, DL, XZ, and YD researched data for the review. LL, SP, MG, AL, and RW edited the manuscript before submission. All authors read and approved the final version of the manuscript.

\section{FUNDING}

This work was funded by the National Natural Science Foundation of China (No. 81970717), Key R\&D projects of Jiangsu Province (No. BE 2018742), and Joint Key Project of Southeast University \& Nanjing Medical University (No. 2242019K3DN07).

Aiswarya, Y., Shivaprasad, C., Anish, K., Sridevi, A., Anupam, B., and Amit, G. (2019). Assessment of insulin sensitivity and secretion in patients with fibrocalculous pancreatic diabetes. Diabetes Metab. Syndr. Obes. 12, 779-788. doi: $10.2147 / \mathrm{dmso.S204254}$

Alexandre-Heymann, L., Lemoine, A. Y., Nakib, S., Kapel, N., Ledoux, S., and Larger, E. (2019). Nutritional markers in patients with diabetes and pancreatic exocrine failure. Acta Diabetol. 56, 651-658. doi: 10.1007/s00592019-01294-w

Alves, C., Batel-Marques, F., and Macedo, A. F. (2012). A meta-analysis of serious adverse events reported with exenatide and liraglutide: acute pancreatitis and cancer. Diabetes Res. Clin. Pract. 98, 271-284. doi: 10.1016/j.diabres.2012. 09.008 
American Diabetes Association (2019). 2. Classification and Diagnosis of Diabetes: Standards of Medical Care in Diabetes-2019. Diabetes Care 42, S13-S28. doi: $10.2337 / \mathrm{dc} 19-\mathrm{S} 002$

Andersen, A., Lund, A., Knop, F. K., and Vilsboll, T. (2018). Glucagon-like peptide 1 in health and disease. Nat. Rev. Endocrinol. 14, 390-403. doi: 10.1038/s41574018-0016-2

Andersen, B. N., Hagen, C., Klein, H. C., Stadil, F., and Worning, H. (1980). Correlation between exocrine pancreatic secretion and serum concentration of human pancreatic polypeptide in chronic pancreatitis. Scand. J. Gastroenterol. 15, 699-704. doi: 10.3109/00365528009181517

Apte, M., Pirola, R., and Wilson, J. (2011). The fibrosis of chronic pancreatitis: new insights into the role of pancreatic stellate cells. Antioxid. Redox. Signal. 15, 2711-2722. doi: 10.1089/ars.2011.4079

Apte, M., Pirola, R. C., and Wilson, J. S. (2015). Pancreatic stellate cell: physiologic role, role in fibrosis and cancer. Curr. Opin. Gastroenterol. 31, 416-423. doi: 10.1097/mog.0000000000000196

Apte, M. V., Haber, P. S., Applegate, T. L., Norton, I. D., Mccaughan, G. W., Korsten, M. A., et al. (1998). Periacinar stellate shaped cells in rat pancreas: identification, isolation, and culture. Gut 43, 128-133. doi: 10.1136/gut.43. 1.128

Armutcu, F. (2019). Organ crosstalk: the potent roles of inflammation and fibrotic changes in the course of organ interactions. Inflamm. Res. 68, 825-839. doi: 10.1007/s00011-019-01271-7

Azoulay, L., Filion, K. B., Platt, R. W., Dahl, M., Dormuth, C. R., Clemens, K. K., et al. (2016). Association between incretin-based drugs and the risk of Acute Pancreatitis. JAMA Intern. Med. 176, 1464-1473. doi: 10.1001/jamainternmed. 2016.1522

Beger, H. G., Poch, B., Mayer, B., and Siech, M. (2018). New onset of diabetes and pancreatic exocrine insufficiency after pancreaticoduodenectomy for benign and malignant tumors: a systematic review and meta-analysis of long-term results. Ann. Surg. 267, 259-270. doi: 10.1097/sla.0000000000002422

Bellin, M. D., Whitcomb, D. C., Abberbock, J., Sherman, S., Sandhu, B. S., Gardner, T. B., et al. (2017). Patient and Disease Characteristics Associated With the Presence of Diabetes Mellitus in Adults With Chronic Pancreatitis in the United States. Am. J. Gastroenterol. 112, 1457-1465. doi: 10.1038/ajg.2017.181

Bensellam, M., Jonas, J. C., and Laybutt, D. R. (2018). Mechanisms of beta-cell dedifferentiation in diabetes: recent findings and future research directions. J. Endocrinol. 236, R109-R143. doi: 10.1530/joe-17-0516

Bharmal, S. H., Cho, J., Alarcon Ramos, G. C., Ko, J., Stuart, C. E., Modesto, A. E., et al. (2020a). Trajectories of glycaemia following acute pancreatitis: a prospective longitudinal cohort study with 24 months follow-up. J. Gastroenterol. 55, 775-788. doi: 10.1007/s00535-020-01682-y

Bharmal, S. H., Cho, J., Stuart, C. E., Alarcon Ramos, G. C., Ko, J., and Petrov, M. S. (2020b). Oxyntomodulin May Distinguish New-Onset Diabetes After Acute Pancreatitis From Type 2 Diabetes. Clin. Transl. Gastroenterol. 11:e00132. doi: $10.14309 /$ ctg.0000000000000132

Bonner-Weir, S., Guo, L., Li, W. C., Ouziel-Yahalom, L., Lysy, P. A., Weir, G. C., et al. (2012). Islet neogenesis: a possible pathway for beta-cell replenishment. Rev. Diabet. Stud. 9, 407-416. doi: 10.1900/rds.2012.9.407

Brunicardi, F. C., Chaiken, R. L., Ryan, A. S., Seymour, N. E., Hoffmann, J. A., Lebovitz, H. E., et al. (1996). Pancreatic polypeptide administration improves abnormal glucose metabolism in patients with chronic pancreatitis. J. Clin. Endocrinol. Metab. 81, 3566-3572. doi: 10.1210/jcem.81.10.8855802

Buse, J. B., Bethel, M. A., Green, J. B., Stevens, S. R., Lokhnygina, Y., Aschner, P., et al. (2017). Pancreatic Safety of Sitagliptin in the TECOS Study. Diabetes Care 40, 164-170. doi: 10.2337/dc15-2780

Campbell, J. E., and Drucker, D. J. (2015). Islet alpha cells and glucagon-critical regulators of energy homeostasis. Nat. Rev. Endocrinol. 11, 329-338. doi: 10. 1038/nrendo.2015.51

Cerf, M. E. (2013). Beta cell dynamics: beta cell replenishment, beta cell compensation and diabetes. Endocrine 44, 303-311. doi: 10.1007/s12020-0139917-y

Cersosimo, E., Pisters, P. W., Pesola, G., Mcdermott, K., Bajorunas, D., and Brennan, M. F. (1991). Insulin secretion and action in patients with pancreatic cancer. Cancer 67, 486-493.

Chen, C., Cohrs, C. M., Stertmann, J., Bozsak, R., and Speier, S. (2017). Human beta cell mass and function in diabetes: recent advances in knowledge and technologies to understand disease pathogenesis. Mol. Metab. 6, 943-957. doi: 10.1016/j.molmet.2017.06.019

Chera, S., Baronnier, D., Ghila, L., Cigliola, V., Jensen, J. N., Gu, G., et al. (2014). Diabetes recovery by age-dependent conversion of pancreatic delta-cells into insulin producers. Nature 514, 503-507. doi: 10.1038/nature13633

Choudhury, S., Ghosh, S., Gupta, P., Mukherjee, S., and Chattopadhyay, S. (2015). Inflammation-induced ROS generation causes pancreatic cell death through modulation of Nrf2/NF-kappaB and SAPK/JNK pathway. Free Radic. Res. 49, 1371-1383. doi: 10.3109/10715762.2015.1075016

Churm, R., Davies, J. S., Stephens, J. W., and Prior, S. L. (2017). Ghrelin function in human obesity and type 2 diabetes: a concise review. Obes. Rev. 18, 140-148. doi: 10.1111/obr.12474

Cinti, F., Bouchi, R., Kim-Muller, J. Y., Ohmura, Y., Sandoval, P. R., Masini, M., et al. (2016). Evidence of beta-Cell Dedifferentiation in Human Type 2 Diabetes. J. Clin. Endocrinol. Metab. 101, 1044-1054. doi: 10.1210/jc.2015-2860

Collombat, P., Xu, X., Heimberg, H., and Mansouri, A. (2010). Pancreatic betacells: from generation to regeneration. Semin. Cell Dev. Biol. 21, 838-844. doi: 10.1016/j.semcdb.2010.07.007

Criscimanna, A., Coudriet, G. M., Gittes, G. K., Piganelli, J. D., and Esni, F. (2014). Activated macrophages create lineage-specific microenvironments for pancreatic acinar- and beta-cell regeneration in mice. Gastroenterology 147, 1106-1118.e1111. doi: 10.1053/j.gastro.2014.08.008

Da Silva Xavier, G. (2018). The cells of the islets of Langerhans. J. Clin. Med. 7:54. doi: $10.3390 / \mathrm{jcm} 7030054$

Damsteegt, E. L., Hassan, Z., Hewawasam, N. V., Sarnsamak, K., Jones, P. M., and Hauge-Evans, A. C. (2019). A Novel Role for Somatostatin in the Survival of Mouse Pancreatic Beta Cells. Cell Physiol. Biochem. 52, 486-502. doi: 10.33594/ 000000035

Dasgupta, R., Naik, D., and Thomas, N. (2015). Emerging concepts in the pathogenesis of diabetes in fibrocalculous pancreatic diabetes. J. Diabetes 7 , 754-761. doi: 10.1111/1753-0407.12280

Del Prato, S., Marchetti, P., and Bonadonna, R. C. (2002). Phasic insulin release and metabolic regulation in type 2 diabetes. Diabetes Metab. Res. Rev. 51(Suppl. 1), S109-S116. doi: 10.2337/diabetes.51.2007.s109

Diedisheim, M., Oshima, M., Albagli, O., Huldt, C. W., Ahlstedt, I., Clausen, M., et al. (2018). Modeling human pancreatic beta cell dedifferentiation. Mol. Metab. 10, 74-86. doi: 10.1016/j.molmet.2018.02.002

DiGruccio, M. R., Mawla, A. M., Donaldson, C. J., Noguchi, G. M., Vaughan, J., Cowing-Zitron, C., et al. (2016). Comprehensive alpha, beta and delta cell transcriptomes reveal that ghrelin selectively activates delta cells and promotes somatostatin release from pancreatic islets. Mol. Metab. 5, 449-458. doi: 10. 1016/j.molmet.2016.04.007

Duggan, S. N., and Conlon, K. C. (2013). Bone health guidelines for patients with chronic pancreatitis. Gastroenterology 145:911. doi: 10.1053/j.gastro.2013. 06.058

Ebert, R., and Creutzfeldt, W. (1980). Reversal of impaired GIP and insulin secretion in patients with pancreatogenic steatorrhea following enzyme substitution. Diabetologia 19, 198-204. doi: 10.1007/bf00275269

El Sayed, S. A., and Mukherjee, S. (2019). "Physiology, Pancreas-StatPearls. Treasure Island (FL): StatPearls Publishing StatPearls Publishing LLC. Available online at: https://pubmed.ncbi.nlm.nih.gov/29083590/

Ewald, N., and Bretzel, R. G. (2013). Diabetes mellitus secondary to pancreatic diseases (Type 3c)-are we neglecting an important disease? Eur. J. Intern. Med. 24, 203-206. doi: 10.1016/j.ejim.2012.12.017

Ewald, N., and Hardt, P. D. (2013). Diagnosis and treatment of diabetes mellitus in chronic pancreatitis. World J. Gastroenterol. 19, 7276-7281. doi: 10.3748/wjg. v19.i42.7276

Ewald, N., Kaufmann, C., Raspe, A., Kloer, H. U., Bretzel, R. G., and Hardt, P. D. (2012). Prevalence of diabetes mellitus secondary to pancreatic diseases (type 3c). Diabetes Metab. Res. Rev. 28, 338-342. doi: 10.1002/dmrr.2260

Galadari, S., Rahman, A., Pallichankandy, S., Galadari, A., and Thayyullathil, F. (2013). Role of ceramide in diabetes mellitus: evidence and mechanisms. Lipids Health Dis. 12:98. doi: 10.1186/1476-511x-12-98

Gilliland, T. M., Villafane-Ferriol, N., Shah, K. P., Shah, R. M., Tran Cao, H. S., Massarweh, N. N., et al. (2017). Nutritional and metabolic derangements in pancreatic cancer and pancreatic resection. Nutrients 9:243. doi: 10.3390/ nu9030243 
Girish, B. N., Rajesh, G., Vaidyanathan, K., and Balakrishnan, V. (2011). Alterations in plasma amino acid levels in chronic pancreatitis. JOP 12, 11-18.

Gold-Smith, F. D., Singh, R. G., and Petrov, M. S. (2020). Elevated circulating levels of motilin are associated with diabetes in individuals after acute Pancreatitis. Exp. Clin. Endocrinol. Diabetes 128, 43-51. doi: 10.1055/a-0859-7168

Gomez-Cerezo, J., Garces, M. C., Codoceo, R., Soto, A., Arnalich, F., Barbado, J., et al. (1996). Postprandial glucose-dependent insulinotropic polypeptide and insulin responses in patients with chronic pancreatitis with and without secondary diabetes. Regul. Pept. 67, 201-205. doi: 10.1016/s0167-0115(96) 00135-8

Goodarzi, M. O., Nagpal, T., Greer, P., Cui, J., Chen, Y. I., Guo, X., et al. (2019). Genetic risk score in diabetes associated with chronic Pancreatitis versus type 2 diabetes mellitus. Clin. Transl. Gastroenterol. 10:e00057. doi: 10.14309/ctg. 0000000000000057

Gromada, J., Chabosseau, P., and Rutter, G. A. (2018). The alpha-cell in diabetes mellitus. Nat. Rev. Endocrinol. 14, 694-704. doi: 10.1038/s41574-018-0097-y

Gudipaty, L., and Rickels, M. R. (2015). Pancreatogenic (Type 3c) Diabetes. Pancreapedia: Exocrine Pancreas Knowledge Base.

Gukovsky, I., Li, N., Todoric, J., Gukovskaya, A., and Karin, M. (2013). Inflammation, autophagy, and obesity: common features in the pathogenesis of pancreatitis and pancreatic cancer. Gastroenterology 144, 1199-1209.e1194. doi: 10.1053/j.gastro.2013.02.007

Habtezion, A., Gukovskaya, A. S., and Pandol, S. J. (2019). Acute Pancreatitis: a multifaceted set of organelle and cellular interactions. Gastroenterology 156, 1941-1950. doi: 10.1053/j.gastro.2018.11.082

Halim, M., and Halim, A. (2019). The effects of inflammation, aging and oxidative stress on the pathogenesis of diabetes mellitus (type 2 diabetes). Diabetes Metab. Syndr. 13, 1165-1172. doi: 10.1016/j.dsx.2019.01.040

Hallac, A., Aleassa, E. M., Rogers, M., Falk, G. A., and Morris-Stiff, G. (2019). Exocrine pancreatic insufficiency in distal pancreatectomy: incidence and risk factors. HPB 22, 275-281. doi: 10.1016/j.hpb.2019.06.017

Hammad, A. Y., Ditillo, M., and Castanon, L. (2018). Pancreatitis. Surg. Clin. North. Am. 98, 895-913. doi: 10.1016/j.suc.2018.06.001

Hanafusa, T., Toyoshima, H., Nonaka, K., and Tarui, S. (1982). Impaired response of human pancreatic polypeptide to insulin-induced hypoglycemia in chronic pancreatitis without diabetes mellitus. Endocrinol. Jpn. 29, 509-515. doi: 10. 1507/endocrj1954.29.509

Hart, P. A., Andersen, D. K., Mather, K. J., Castonguay, A. C., Bajaj, M., Bellin, M. D., et al. (2018). Evaluation of a Mixed Meal Test for Diagnosis and Characterization of PancrEaTogEniC diabetes secondary to pancreatic cancer and chronic pancreatitis: rationale and methodology for the DETECT Study From the Consortium for the Study of Chronic Pancreatitis. Diabetes, and Pancreatic Cancer. Pancreas 47, 1239-1243. doi: 10.1097/mpa. 0000000000001168

Hart, P. A., Bellin, M. D., Andersen, D. K., Bradley, D., Cruz-Monserrate, Z., Forsmark, C. E., et al. (2016). Type 3c (pancreatogenic) diabetes mellitus secondary to chronic pancreatitis and pancreatic cancer. Lancet Gastroenterol. Hepatol. 1, 226-237. doi: 10.1016/s2468-1253(16)30106-6

Hedetoft, C., Sheikh, S. P., Larsen, S., and Holst, J. J. (2000). Effect of glucagonlike peptide 1(7-36)amide in insulin-treated patients with diabetes mellitus secondary to chronic pancreatitis. Pancreas 20, 25-31.

Hennig, R., Kekis, P. B., Friess, H., Adrian, T. E., and Buchler, M. W. (2002). Pancreatic polypeptide in pancreatitis. Peptides 23, 331-338. doi: 10.1016/ s0196-9781(01)00605-2

Holst, J. J., Vilsboll, T., and Deacon, C. F. (2009). The incretin system and its role in type 2 diabetes mellitus. Mol. Cell. Endocrinol. 297, 127-136. doi: 10.1016/j. mce.2008.08.012

Huang, W., De La Iglesia-Garcia, D., Baston-Rey, I., Calvino-Suarez, C., LarinoNoia, J., Iglesias-Garcia, J., et al. (2019). Exocrine pancreatic insufficiency following acute Pancreatitis: systematic review and meta-analysis. Dig. Dis. Sci. 64, 1985-2005. doi: 10.1007/s10620-019-05568-9

Imai, Y., Dobrian, A. D., Morris, M. A., Taylor-Fishwick, D. A., and Nadler, J. L. (2016). Lipids and immunoinflammatory pathways of beta cell destruction. Diabetologia 59, 673-678. doi: 10.1007/s00125-016-3890-y

Jandhyala, S. M., Madhulika, A., Deepika, G., Rao, G. V., Reddy, D. N., Subramanyam, C., et al. (2017). Altered intestinal microbiota in patients with chronic pancreatitis: implications in diabetes and metabolic abnormalities. Sci. Rep. 7:43640. doi: 10.1038/srep43640
Jawahar, A. P., Narayanan, S., Loganathan, G., Pradeep, J., Vitale, G. C., Jones, C. M., et al. (2019). Ductal Cell Reprogramming to Insulin-Producing Beta-Like Cells as a Potential Beta Cell Replacement Source for Chronic Pancreatitis. Curr. Stem Cell Res. Ther. 14, 65-74. doi: 10.2174/1574888x13666180918092729

Jethwa, P., Sodergren, M., Lala, A., Webber, J., Buckels, J. A., Bramhall, S. R., et al. (2006). Diabetic control after total pancreatectomy. Dig. Liver Dis. 38, 415-419. doi: 10.1016/j.dld.2006.01.022

Joanette, E. A., Reusens, B., Arany, E., Thyssen, S., Remacle, R. C., and Hill, D. J. (2004). Low-protein diet during early life causes a reduction in the frequency of cells immunopositive for nestin and CD34 in both pancreatic ducts and islets in the rat. Endocrinology 145, 3004-3013. doi: 10.1210/en.2003-0796

Jonas, J. C., Sharma, A., Hasenkamp, W., Ilkova, H., Patane, G., Laybutt, R., et al. (1999). Chronic hyperglycemia triggers loss of pancreatic beta cell differentiation in an animal model of diabetes. J. Biol. Chem. 274, 14112-14121.

Kaneko, Y. K., and Ishikawa, T. (2015). Diacylglycerol Signaling Pathway in Pancreatic beta-Cells: an essential role of Diacylglycerol Kinase in the Regulation of Insulin Secretion. Biol. Pharm. Bull. 38, 669-673. doi: 10.1248/ bpb.b15-00060

Kien, C. L., Horswill, C. A., Zipf, W. B., Mccoy, K. S., and O'dorisio, T. (1995). Elevated hepatic glucose production in children with cystic fibrosis. Pediatr. Res. 37, 600-605. doi: 10.1203/00006450-199505000-00007

Kim, W., Fiori, J. L., Shin, Y.-K., Okun, E., Kim, J. S., Rapp, P. R., et al. (2014). Pancreatic polypeptide inhibits somatostatin secretion. FEBS Lett. 588, 32333239. doi: 10.1016/j.febslet.2014.07.005

Knop, F. K. (2010). Incretin hormones and beta cell function in chronic pancreatitis. Dan. Med. Bull. 57:B4163.

Knop, F. K., Vilsboll, T., Hojberg, P. V., Larsen, S., Madsbad, S., Holst, J. J., et al. (2007a). The insulinotropic effect of GIP is impaired in patients with chronic pancreatitis and secondary diabetes mellitus as compared to patients with chronic pancreatitis and normal glucose tolerance. Regul. Pept. 144, 123-130. doi: 10.1016/j.regpep.2007.07.002

Knop, F. K., Vilsboll, T., Hojberg, P. V., Larsen, S., Madsbad, S., Volund, A., et al. (2007b). Reduced incretin effect in type 2 diabetes: cause or consequence of the diabetic state? Diabetes 56, 1951-1959. doi: 10.2337/db07-0100

Knop, F. K., Vilsboll, T., Larsen, S., Hojberg, P. V., Volund, A., Madsbad, S., et al. (2007c). Increased postprandial responses of GLP-1 and GIP in patients with chronic pancreatitis and steatorrhea following pancreatic enzyme substitution. Am. J. Physiol. Endocrinol. Metab. 292, E324-E330. doi: 10.1152/ajpendo.00059. 2006

Koehler, J. A., Baggio, L. L., Lamont, B. J., Ali, S., and Drucker, D. J. (2009). Glucagon-like peptide-1 receptor activation modulates pancreatitis-associated gene expression but does not modify the susceptibility to experimental pancreatitis in mice. Diabetes Metab. Res. Rev. 58, 2148-2161. doi: 10.2337/ db09-0626

Kumar, K., Manrai, M., Sood, A. K., and Sharma, R. (2017). A clinical study of insulin resistance in patients with chronic pancreatitis. Diabetes Metab. Syndr. 11(Suppl. 1), S283-S286. doi: 10.1016/j.dsx.2017.03.003

Kurrer, M. O., Pakala, S. V., Hanson, H. L., and Katz, J. D. (1997). Beta cell apoptosis in T cell-mediated autoimmune diabetes. Proc. Natl. Acad. Sci. U.S.A. 94, 213-218. doi: 10.1073/pnas.94.1.213

Kusakabe, J., Anderson, B., Liu, J., Williams, G. A., Chapman, W. C., Doyle, M. M. B., et al. (2019). Long-term endocrine and exocrine insufficiency after pancreatectomy. J. Gastrointest. Surg. 23, 1604-1613. doi: 10.1007/s11605-01804084-x

Lardon, J., Rooman, I., and Bouwens, L. (2002). Nestin expression in pancreatic stellate cells and angiogenic endothelial cells. Histochem. Cell Biol. 117, 535-540. doi: 10.1007/s00418-002-0412-4

Larsen, S. (1993). Diabetes mellitus secondary to chronic pancreatitis. Dan. Med. Bull. 40, 153-162.

Larsen, S., Hilsted, J., Philipsen, E. K., Tronier, B., Christensen, N. J., Damkjaer Nielsen, M., et al. (1990). Glucose counterregulation in diabetes secondary to chronic pancreatitis. Metabolism 39, 138-143. doi: 10.1016/0026-0495(90) 90066-1

Larsen, S., Hilsted, J., Tronier, B., and Worning, H. (1987). Metabolic control and $\mathrm{B}$ cell function in patients with insulin-dependent diabetes mellitus secondary to chronic pancreatitis. Metabolism 36, 964-967. doi: 10.1016/0026-0495(87) 90133-8 
Larsen, S., Hilsted, J., Tronier, B., and Worning, H. (1988). Pancreatic hormone secretion in chronic pancreatitis without residual beta-cell function. Acta Endocrinol. 118, 357-364. doi: 10.1530/acta.0.1180357

Lee, J., Sugiyama, T., Liu, Y., Wang, J., Gu, X., Lei, J., et al. (2013). Expansion and conversion of human pancreatic ductal cells into insulin-secreting endocrine cells. eLife 2:e00940. doi: 10.7554/eLife.00940

Li, X., Jia, L., Chen, X., Dong, Y., Ren, X., Dong, Y., et al. (2018). Islet alphacell Inflammation Induced By NF-kappaB inducing kinase (NIK) Leads to Hypoglycemia, Pancreatitis, Growth Retardation, and Postnatal Death in Mice. Theranostics 8, 5960-5971. doi: 10.7150/thno.28960

Liao, W. C., Huang, B. S., Yu, Y. H., Yang, H. H., Chen, P. R., Huang, C. C., et al. (2019). Galectin-3 and S100A9: novel diabetogenic factors mediating pancreatic cancer-associated diabetes. Diabetes Care 42, 1752-1759. doi: 10.2337/dc190217

Lin, Y. K., Johnston, P. C., Arce, K., and Hatipoglu, B. A. (2015). Chronic Pancreatitis and Diabetes Mellitus. Curr. Treat. Options Gastroenterol. 13, 319-331. doi: 10.1007/s11938-015-0055-x

Lohr, J. M., Dominguez-Munoz, E., Rosendahl, J., Besselink, M., Mayerle, J., Lerch, M. M., et al. (2017). United European Gastroenterology evidence-based guidelines for the diagnosis and therapy of chronic pancreatitis (HaPanEU). United Eur. Gastroenterol. J. 5, 153-199. doi: 10.1177/2050640616684695

Magenheim, J., Klein, A. M., Stanger, B. Z., Ashery-Padan, R., Sosa-Pineda, B., $\mathrm{Gu}, \mathrm{G}$., et al. (2011). Ngn3(+) endocrine progenitor cells control the fate and morphogenesis of pancreatic ductal epithelium. Dev. Biol. 359, 26-36. doi: 10.1016/j.ydbio.2011.08.006

Maulucci, G., Daniel, B., Cohen, O., Avrahami, Y., and Sasson, S. (2016). Hormetic and regulatory effects of lipid peroxidation mediators in pancreatic beta cells. Mol. Aspects Med. 49, 49-77. doi: 10.1016/j.mam.2016.03.001

Mayerle, J., Sendler, M., Hegyi, E., Beyer, G., Lerch, M. M., and Sahin-Toth, M. (2019). Genetics, Cell Biology, and Pathophysiology of Pancreatitis. Gastroenterology 156, 1951-1968.e1951. doi: 10.1053/j.gastro.2018.11.081

Meier, J. J., and Giese, A. (2015). Diabetes associated with pancreatic diseases. Curr. Opin. Gastroenterol. 31, 400-406. doi: 10.1097/mog.0000000000000199

Expert Committee on the Diagnosis and Classification of Diabetes Mellitus (2003). Report of the expert committee on the diagnosis and classification of diabetes mellitus. Diabetes Care 26(Suppl. 1), S5-S20. doi: 10.2337/diacare.26.2007.s5

Memba, R., Duggan, S. N., Ni Chonchubhair, H. M., Griffin, O. M., Bashir, Y., O'connor, D. B., et al. (2017). The potential role of gut microbiota in pancreatic disease: a systematic review. Pancreatology 17, 867-874. doi: 10.1016/j.pan.2017. 09.002

Moin, A. S. M., Cory, M., Choi, J., Ong, A., Dhawan, S., Dry, S. M., et al. (2018). Increased chromogranin a-positive hormone-negative cells in chronic pancreatitis. J. Clin. Endocrinol. Metab. 103, 2126-2135. doi: 10.1210/jc.201701562

Mumme, L., Breuer, T. G. K., Rohrer, S., Schenker, N., Menge, B. A., Holst, J. J., et al. (2017). Defects in alpha-Cell Function in Patients With Diabetes Due to Chronic Pancreatitis Compared With Patients With Type 2 Diabetes and Healthy Individuals. Diabetes Care 40, 1314-1322. doi: 10.2337/dc17-0792

Munoz-Garach, A., Garcia-Fontana, B., and Munoz-Torres, M. (2019). Vitamin D Status, Calcium Intake and Risk of Developing Type 2 Diabetes: an unresolved issue. Nutrients 11:642. doi: 10.3390/nu11030642

Nagpal, S. J. S., Bamlet, W. R., Kudva, Y. C., and Chari, S. T. (2018). Comparison of Fasting Human Pancreatic Polypeptide Levels Among Patients With Pancreatic Ductal Adenocarcinoma, Chronic Pancreatitis, and Type 2 Diabetes Mellitus. Pancreas 47, 738-741. doi: 10.1097/mpa.0000000000001077

Napolitano, T., Silvano, S., Vieira, A., Balaji, S., Garrido-Utrilla, A., Friano, M. E., et al. (2018). Role of ghrelin in pancreatic development and function. Diabetes Obes. Metab. 20(Suppl. 2), 3-10. doi: 10.1111/dom. 13385

Nauck, M. A., Heimesaat, M. M., Orskov, C., Holst, J. J., Ebert, R., and Creutzfeldt, W. (1993). Preserved incretin activity of glucagon-like peptide 1 [7-36 amide] but not of synthetic human gastric inhibitory polypeptide in patients with type-2 diabetes mellitus. J. Clin. Invest. 91, 301-307. doi: 10.1172/jci116186

Niebisz-Cieslak, A. B., and Karnafel, W. (2010). Insulin sensitivity in chronic pancreatitis and features of insulin resistance syndrome. Pol. Arch. Med. Wewn 120, 255-263.

Nyirjesy, S. C., Sheikh, S., Hadjiliadis, D., De Leon, D. D., Peleckis, A. J., Eiel, J. N., et al. (2018). beta-Cell secretory defects are present in pancreatic insufficient cystic fibrosis with 1-hour oral glucose tolerance test glucose $>/=155 \mathrm{mg} / \mathrm{dL}$. Pediatr. Diabetes 19, 1173-1182. doi: 10.1111/pedi.12700

O'Brien, S. J., and Omer, E. (2019). Chronic pancreatitis and nutrition therapy. Nutr. Clin. Pract. 34(Suppl. 1), S13-S26. doi: 10.1002/ncp.10379

Olesen, S. S., Krarup, H., Poulsen, J. L., Christensen, J. H., Sheel, A. R. G., Sutton, R., et al. (2019). Pancreas-specific plasma amylase for assessment and diagnosis of chronic pancreatitis: new insights on an old topic. United Eur. Gastroenterol. J. 7, 955-964. doi: 10.1177/2050640619846011

Omary, M. B., Lugea, A., Lowe, A. W., and Pandol, S. J. (2007). The pancreatic stellate cell: a star on the rise in pancreatic diseases. J. Clin. Invest. 117, 50-59. doi: $10.1172 /$ jci30082

Ouyang, D., Dhall, D., and Yu, R. (2011). Pathologic pancreatic endocrine cell hyperplasia. World J. Gastroenterol. 17, 137-143. doi: 10.3748/wjg.v17.i2.137

Papazachariou, I. M., Martinez-Isla, A., Efthimiou, E., Williamson, R. C., and Girgis, S. I. (2000). Magnesium deficiency in patients with chronic pancreatitis identified by an intravenous loading test. Clin. Chim. Acta 302, 145-154. doi: 10.1016/s0009-8981(00)00363-6

Pavan Kumar, P., Radhika, G., Rao, G. V., Pradeep, R., Subramanyam, C., Talukdar, R., et al. (2012). Interferon gamma and glycemic status in diabetes associated with chronic pancreatitis. Pancreatology 12, 65-70. doi: 10.1016/j.pan.2011. 12.005

Pendharkar, S. A., Mathew, J., and Petrov, M. S. (2017). Age- and sex-specific prevalence of diabetes associated with diseases of the exocrine pancreas: a population-based study. Dig. Liver Dis. 49, 540-544. doi: 10.1016/j.dld.2016. 12.010

Petrov, M. S. (2017). Diabetes of the exocrine pancreas: american Diabetes Association-compliant lexicon. Pancreatology 17, 523-526. doi: 10.1016/j.pan. 2017.06.007

Petrov, M. S., and Yadav, D. (2019). Global epidemiology and holistic prevention of pancreatitis. Nat. Rev. Gastroenterol. Hepatol. 16, 175-184. doi: 10.1038/ s41575-018-0087-5

Pham, A., and Forsmark, C. (2018). Chronic pancreatitis: review and update of etiology, risk factors, and management. F1000Res 7:F1000 Faculty Rev-607. doi: 10.12688/f1000research.12852.1

Pondugala, P. K., Sasikala, M., Guduru, V. R., Rebala, P., and Nageshwar Reddy, D. (2015). Interferon-gamma Decreases Nuclear Localization of Pdx-1 and Triggers beta-Cell Dysfunction in Chronic Pancreatitis. J. Interferon Cytokine Res. 35, 523-529. doi: 10.1089/jir.2014.0082

Rahier, J., Guiot, Y., Goebbels, R. M., Sempoux, C., and Henquin, J. C. (2008). Pancreatic beta-cell mass in European subjects with type 2 diabetes. Diabetes Obes. Metab. 10(Suppl. 4), 32-42. doi: 10.1111/j.1463-1326.2008.00969.x

Rahier, J., Wallon, J., Loozen, S., Lefevre, A., Gepts, W., and Haot, J. (1983). The pancreatic polypeptide cells in the human pancreas: the effects of age and diabetes. J. Clin. Endocrinol. Metab. 56, 441-444. doi: 10.1210/jcem-56-3-441

Rasmussen, H. H., Irtun, O., Olesen, S. S., Drewes, A. M., and Holst, M. (2013). Nutrition in chronic pancreatitis. World J. Gastroenterol. 19, 7267-7275. doi: 10.3748/wjg.v19.i42.7267

Rickels, M. R., Bellin, M., Toledo, F. G., Robertson, R. P., Andersen, D. K., Chari, S. T., et al. (2013). Detection, evaluation and treatment of diabetes mellitus in chronic pancreatitis: recommendations from PancreasFest 2012. Pancreatology 13, 336-342. doi: 10.1016/j.pan.2013.05.002

Rojas, J., Bermudez, V., Palmar, J., Martinez, M. S., Olivar, L. C., Nava, M., et al. (2018). Pancreatic beta cell death: novel potential mechanisms in diabetes therapy. J. Diabetes Res. 2018:9601801. doi: 10.1155/2018/9601801

Rorsman, P., and Huising, M. O. (2018). The somatostatin-secreting pancreatic delta-cell in health and disease. Nat. Rev. Endocrinol. 14, 404-414. doi: 10.1038/ s41574-018-0020-6

Sakata, N., Yoshimatsu, G., and Kodama, S. (2019). Development and characteristics of pancreatic epsilon cells. Int. J. Mol. Sci. 20:1867. doi: 10.3390/ ijms20081867

Sasaki, S., Miyatsuka, T., Matsuoka, T. A., Takahara, M., Yamamoto, Y., Yasuda, T., et al. (2015). Activation of GLP-1 and gastrin signalling induces in vivo reprogramming of pancreatic exocrine cells into beta cells in mice. Diabetologia 58, 2582-2591. doi: 10.1007/s00125-015-3728-z

Sasikala, M., Talukdar, R., Pavan Kumar, P., Radhika, G., Rao, G. V., Pradeep, R., et al. (2012). beta-Cell dysfunction in chronic pancreatitis. Dig. Dis. Sci. 57, 1764-1772. doi: 10.1007/s10620-012-2086-7 
Schrader, H., Menge, B. A., Schneider, S., Belyaev, O., Tannapfel, A., Uhl, W., et al. (2009). Reduced pancreatic volume and beta-cell area in patients with chronic pancreatitis. Gastroenterology 136, 513-522. doi: 10.1053/j.gastro.2008. 10.083

Seymour, N. E., Brunicardi, F. C., Chaiken, R. L., Lebovitz, H. E., Chance, R. E., Gingerich, R. L., et al. (1988). Reversal of abnormal glucose production after pancreatic resection by pancreatic polypeptide administration in man. Surgery 104, 119-129.

Sharma, A., Yerra, V. G., and Kumar, A. (2017). Emerging role of Hippo signalling in pancreatic biology: YAP re-expression and plausible link to islet cell apoptosis and replication. Biochimie 133, 56-65. doi: 10.1016/j.biochi.2016.12.009

Sheikh, S., Gudipaty, L., De Leon, D. D., Hadjiliadis, D., Kubrak, C., Rosenfeld, N. K., et al. (2017). Reduced beta-Cell Secretory Capacity in PancreaticInsufficient, but Not Pancreatic-Sufficient, Cystic Fibrosis Despite Normal Glucose Tolerance. Diabetes Metab. Res. Rev. 66, 134-144. doi: 10.2337/db160394

Shi, Q., Hong, Y. P., Zhang, X. Y., Tao, J., Wang, C. Y., Zhao, L., et al. (2018). beta cells can be generated from cytokeratin 5-positive cells after cerulein-induced pancreatitis in adult mice. Biochem. Biophys. Res. Commun. 496, 114-119. doi: 10.1016/j.bbrc.2018.01.008

Shimosegawa, T. (2019). A new insight into chronic pancreatitis. Tohoku J. Exp. Med. 248, 225-238. doi: 10.1620/tjem.248.225

Sit, M., Aktas, G., Yilmaz, E. E., Alcelik, A., Terzi, E. H., and Tosun, M. (2014). Effects of the inflammatory response on serum omentin levels in early acute and chronic pancreatitis. Clin. Ter. 165, e148-e152. doi: 10.7471/ct.2014.1699

Sliwinska-Mosson, M., Marek, G., and Milnerowicz, H. (2017). The role of pancreatic polypeptide in pancreatic diseases. Adv. Clin. Exp. Med. 26, 14471455. doi: 10.17219/acem/65094

Sobczak, A. I. S., Blindauer, C. C., and Stewart, A. J. (2019). Changes in Plasma Free Fatty Acids Associated with Type-2 Diabetes. Nutrients 11:22. doi: 10.3390/ nu11092022

Srivastava, S., Shree, P., Pandey, H., and Tripathi, Y. B. (2018). Incretin hormones receptor signaling plays the key role in antidiabetic potential of PTY-2 against STZ-induced pancreatitis. Biomed. Pharmacother. 97, 330-338. doi: 10.1016/j. biopha.2017.10.071

Sun, J., Ni, Q., Xie, J., Xu, M., Zhang, J., Kuang, J., et al. (2019). beta-Cell Dedifferentiation in Patients With T2D With Adequate Glucose Control and Nondiabetic Chronic Pancreatitis. J. Clin. Endocrinol. Metab. 104, 83-94. doi: 10.1210/jc.2018-00968

Takeshima, K., Ariyasu, H., Iwakura, H., Kawai, S., Uraki, S., Inaba, H., et al. (2018). Predominant Improvement of Alpha Cell function after steroid therapy in a patient with autoimmune pancreatitis: case report. Diabetes Ther. 9, 1385-1395. doi: 10.1007/s13300-018-0434-0

Talchai, C., Xuan, S., Lin, H. V., Sussel, L., and Accili, D. (2012). Pancreatic beta cell dedifferentiation as a mechanism of diabetic beta cell failure. Cell 150, 1223-1234. doi: 10.1016/j.cell.2012.07.029

Talukdar, R., Sasikala, M., Pavan Kumar, P., Rao, G. V., Pradeep, R., and Reddy, D. N. (2016). T-Helper Cell-Mediated Islet Inflammation Contributes to betaCell Dysfunction in Chronic Pancreatitis. Pancreas 45, 434-442. doi: 10.1097/ mpa.0000000000000479

Tan, L., Ye, X., Zhou, Y., Yu, M., Fu, Z., Chen, R., et al. (2014). Macrophage migration inhibitory factor is overexpressed in pancreatic cancer tissues and impairs insulin secretion function of beta-cell. J. Transl. Med. 12:92. doi: 10. 1186/1479-5876-12-92

Tanaka, S., Kobayashi, T., Nakanishi, K., Okubo, M., Murase, T., Hashimoto, M., et al. (2001). Evidence of primary beta-cell destruction by T-cells and beta-cell differentiation from pancreatic ductal cells in diabetes associated with active autoimmune chronic pancreatitis. Diabetes Care 24, 1661-1667. doi: 10.2337/ diacare.24.9.1661

Tasyurek, H. M., Altunbas, H. A., Balci, M. K., and Sanlioglu, S. (2014). Incretins: their physiology and application in the treatment of diabetes mellitus. Diabetes Metab. Res. Rev. 30, 354-371. doi: 10.1002/dmrr.2501

Tilg, H., Zmora, N., Adolph, T. E., and Elinav, E. (2019). The intestinal microbiota fuelling metabolic inflammation. Nat. Rev. Immunol. 20, 40-54. doi: 10.1038/ s41577-019-0198-4

Torres-Fuentes, C., Schellekens, H., Dinan, T. G., and Cryan, J. F. (2017). The microbiota-gut-brain axis in obesity. Lancet Gastroenterol. Hepatol. 2, 747-756. doi: 10.1016/s2468-1253(17)30147-4
Trim, N., Morgan, S., Evans, M., Issa, R., Fine, D., Afford, S., et al. (2000). Hepatic stellate cells express the low affinity nerve growth factor receptor p75 and undergo apoptosis in response to nerve growth factor stimulation. Am. J. Pathol. 156, 1235-1243. doi: 10.1016/s0002-9440(10)64994-2

Tsalamandris, S., Antonopoulos, A. S., Oikonomou, E., Papamikroulis, G. A., Vogiatzi, G., Papaioannou, S., et al. (2019). The role of inflammation in diabetes: current concepts and future perspectives. Eur. Cardiol. 14, 50-59. doi: 10.15420/ ecr.2018.33.1

Tseng, C. M., Liao, W. C., Chang, C. Y., Lee, C. T., Tseng, C. H., Hsu, Y. C., et al. (2017). Incretin-based pharmacotherapy and risk of adverse pancreatic events in the ethnic Chinese with diabetes mellitus: A population-based study in Taiwan. Pancreatology 17, 76-82. doi: 10.1016/j.pan.2016.10.003

Tu, J., Zhang, J., Ke, L., Yang, Y., Yang, Q., Lu, G., et al. (2017). Endocrine and exocrine pancreatic insufficiency after acute pancreatitis: long-term follow-up study. BMC Gastroenterol. 17:114. doi: 10.1186/s12876-017-0663-0

Ueberberg, S., Jutte, H., Uhl, W., Schmidt, W., Nauck, M., Montanya, E., et al. (2016). Histological changes in endocrine and exocrine pancreatic tissue from patients exposed to incretin-based therapies. Diabetes Obes. Metab. 18, 12531262. doi: 10.1111/dom.12766

Van Gassen, N., Staels, W., Van Overmeire, E., De Groef, S., Sojoodi, M., Heremans, Y., et al. (2015). Concise review: macrophages: versatile gatekeepers during pancreatic beta-cell development injury, and regeneration. Stem Cells Transl. Med. 4, 555-563. doi: 10.5966/sctm.2014-0272

Vlasakova, Z., Bartos, V., and Spicak, J. (2002). [Diabetes mellitus in chronic pancreatitis and insulin sensitivity]. Vnitr. Lek. 48, 878-881.

Vujasinovic, M., Hedström, A., Maisonneuve, P., Valente, R., Von Horn, H., Löhr, J. M., et al. (2019). Zinc deficiency in patients with chronic pancreatitis. World J. Gastroenterol. 25, 600-607. doi: 10.3748/wjg.v25.i5.600

Vujasinovic, M., Tepes, B., Makuc, J., Rudolf, S., Zaletel, J., Vidmar, T., et al. (2014). Pancreatic exocrine insufficiency, diabetes mellitus and serum nutritional markers after acute pancreatitis. World J. Gastroenterol. 20, 18432-18438. doi: 10.3748/wjg.v20.i48.18432

Walling, A., and Freelove, R. (2017). Pancreatitis and pancreatic cancer. Prim. Care 44, 609-620. doi: 10.1016/j.pop.2017.07.004

Wang, H., Liu, Y., Tian, Q., Yang, J., Lu, R., Zhan, S., et al. (2018). Incretin-based therapies and risk of pancreatic cancer in patients with type 2 diabetes: a metaanalysis of randomized controlled trials. Diabetes Obes. Metab. 20, 910-920. doi: 10.1111/dom.13177

Wang, T., Wang, F., Gou, Z., Tang, H., Li, C., Shi, L., et al. (2015). Using real-world data to evaluate the association of incretin-based therapies with risk of acute pancreatitis: a meta-analysis of $1,324,515$ patients from observational studies. Diabetes Obes. Metab. 17, 32-41. doi: 10.1111/dom.12386

Webb, M. A., Chen, J. J., James, R. F. L., Davies, M. J., and Dennison, A. R. (2018). Elevated Levels of Alpha Cells Emanating from the Pancreatic Ducts of a Patient with a Low BMI and Chronic Pancreatitis. Cell Transplant. 27, 902-906. doi: $10.1177 / 0963689718755707$

Wierup, N., Svensson, H., Mulder, H., and Sundler, F. (2002). The ghrelin cell: a novel developmentally regulated islet cell in the human pancreas. Regul. Pept. 107, 63-69. doi: 10.1016/s0167-0115(02)00067-8

Woodmansey, C., Mcgovern, A. P., Mccullough, K. A., Whyte, M. B., Munro, N. M., Correa, A. C., et al. (2017). Incidence. Demographics, and Clinical Characteristics of Diabetes of the Exocrine Pancreas (Type 3c): a Retrospective Cohort Study. Diabetes Care 40, 1486-1493. doi: 10.2337/dc17-0542

Wu, C., Qiu, S., Zhu, X., and Li, L. (2017). Vitamin D supplementation and glycemic control in type 2 diabetes patients: a systematic review and metaanalysis. Metabolism 73, 67-76. doi: 10.1016/j.metabol.2017.05.006

Wu, D., Xu, Y., Zeng, Y., and Wang, X. (2011). Endocrine pancreatic function changes after acute pancreatitis. Pancreas 40, 1006-1011. doi: 10.1097/MPA. 0b013e31821fde $3 \mathrm{f}$

Wynne, K., Devereaux, B., and Dornhorst, A. (2019). Diabetes of the exocrine pancreas. J. Gastroenterol. Hepatol. 34, 346-354. doi: 10.1111/jgh.14451

Xiao, X., Fischbach, S., Zhang, T., Chen, C., Sheng, Q., Zimmerman, R., et al. (2017). SMAD3/Stat3 Signaling Mediates beta-Cell Epithelial-Mesenchymal Transition in Chronic Pancreatitis-Related Diabetes. Diabetes Metab. Res. Rev. 66, 2646-2658. doi: 10.2337/db17-0537

Xue, R., Jia, K., Wang, J., Yang, L., Wang, Y., Gao, L., et al. (2018). A rising star in pancreatic diseases: pancreatic stellate cells. Front. Physiol. 9:754. doi: $10.3389 /$ fphys.2018.00754 
Yada, T., Damdindorj, B., Rita, R. S., Kurashina, T., Ando, A., Taguchi, M., et al. (2014). Ghrelin signalling in beta-cells regulates insulin secretion and blood glucose. Diabetes Obes. Metab. 16(Suppl. 1), 111-117. doi: 10.1111/dom.12344

Yamauchi, A., Itaya-Hironaka, A., Sakuramoto-Tsuchida, S., Takeda, M., Yoshimoto, K., Miyaoka, T., et al. (2015). Synergistic activations of REG I alpha and REG I beta promoters by IL-6 and Glucocorticoids through JAK/STAT pathway in human pancreatic beta cells. J. Diabetes Res. 2015:173058. doi: $10.1155 / 2015 / 173058$

Yang, Y., Yu, X., Huang, L., and Yu, C. (2013). GLP-1R agonist may activate pancreatic stellate cells to induce rat pancreatic tissue lesion. Pancreatology 13 , 498-501. doi: 10.1016/j.pan.2013.07.281

Yki-Jarvinen, H., Kiviluoto, T., and Taskinen, M. R. (1986). Insulin resistance is a prominent feature of patients with pancreatogenic diabetes. Metabolism 35, 718-727. doi: 10.1016/0026-0495(86)90239-8

Zammitt, N. N., and Frier, B. M. (2005). Hypoglycemia in type 2 diabetes: pathophysiology, frequency, and effects of different treatment modalities. Diabetes Care 28, 2948-2961. doi: 10.2337/diacare.28.12.2948

Zang, G., Sandberg, M., Carlsson, P. O., Welsh, N., Jansson, L., and Barbu, A. (2015). Activated pancreatic stellate cells can impair pancreatic islet function in mice. Ups. J. Med. Sci. 120, 169-180. doi: 10.3109/03009734.2015.1032453
Zechner, D., Knapp, N., Bobrowski, A., Radecke, T., Genz, B., and Vollmar, B. (2014). Diabetes increases pancreatic fibrosis during chronic inflammation. Exp. Biol. Med. 239, 670-676. doi: 10.1177/1535370214527890

Zha, M., Xu, W., Zhai, Q., Li, F., Chen, B., and Sun, Z. (2014). High glucose aggravates the detrimental effects of pancreatic stellate cells on Beta-cell function. Int. J. Endocrinol. 2014:165612. doi: 10.1155/2014/165612

Zhou, Q., and Melton, D. A. (2018). Pancreas regeneration. Nature 557, 351-358. doi: 10.1038/s41586-018-0088-0

Conflict of Interest: The authors declare that the research was conducted in the absence of any commercial or financial relationships that could be construed as a potential conflict of interest.

Copyright $\odot 2020$ Wei, Qi, Lin, Liu, Zhu, Dai, Waldron, Lugea, Goodarzi, Pandol and Li. This is an open-access article distributed under the terms of the Creative Commons Attribution License (CC BY). The use, distribution or reproduction in other forums is permitted, provided the original author(s) and the copyright owner(s) are credited and that the original publication in this journal is cited, in accordance with accepted academic practice. No use, distribution or reproduction is permitted which does not comply with these terms. 